\title{
Selenium hyperaccumulators harbor a diverse endophytic bacterial community characterized by high selenium resistance and plant growth promoting properties
}

\author{
Martina Sura-de Jong ${ }^{1,2}$, Ray J. B. Reynolds ${ }^{3}$, Klara Richterova ${ }^{1}$, Lucie Musilova ${ }^{1}$, Lucian C. Staicu ${ }^{3}$, \\ Iva Chocholata ${ }^{1}$, Jennifer J. Cappa ${ }^{3}$, Safiyh Taghavi ${ }^{4}$, Daniel van der Lelie ${ }^{4}$, Tomas Frantik ${ }^{5}$, \\ Iva Dolinova ${ }^{6}$, Michal Strejcek ${ }^{1}$, Alyssa T. Cochran ${ }^{3}$, Petra Lovecka ${ }^{1}$ and Elizabeth A. H. Pilon-Smits ${ }^{3 *}$ \\ ${ }^{1}$ Department of Biochemistry and Microbiology, University of Chemistry and Technology in Prague, Prague, Czech Republic \\ 2 Life Sciences and Technology, Van Hall Larenstein University of Applied Sciences, Leeuwarden, Netherlands \\ ${ }^{3}$ Biology Department, Colorado State University, Fort Collins, CO, USA \\ ${ }^{4}$ FMC Corporation, Center of Excellence for Agricultural Biosolutions, Research Triangle Park, NC, USA \\ 5 Institute of Botany, Academy of Sciences of the Czech Republic, Pruhonice, Czech Republic \\ ${ }^{6}$ The Institute for Nanomaterials, Advanced Technology and Innovation, Technical University of Liberec, Liberec, Czech Republic
}

Edited by:

Antonella Furini, University of Verona, Italy

Reviewed by:

Paulo Arruda, Universidade Estadual de Campinas, Brazil

Anna Maria Sanangelantoni,

University of Parma, Italy

\section{*Correspondence:}

Elizabeth A. H. Pilon-Smits, Biology

Department, Colorado State

University, 200 West Lake Street,

Fort Collins, CO 80523-1878, USA

e-mail: epsmits@lamar.

colostate.edu
Selenium (Se)-rich plants may be used to provide dietary Se to humans and livestock, and also to clean up Se-polluted soils or waters. This study focused on endophytic bacteria of plants that hyperaccumulate selenium (Se) to $0.5-1 \%$ of dry weight. Terminal restriction fragment length polymorphism (T-RFLP) analysis was used to compare the diversity of endophytic bacteria of hyperaccumulators Stanleya pinnata (Brassicaceae) and Astragalus bisulcatus (Fabaceae) with those from related non-accumulators Physaria bellii (Brassicaceae) and Medicago sativa (Fabaceae) collected on the same, seleniferous site. Hyperaccumulators and non-accumulators showed equal T-RF diversity. Parsimony analysis showed that T-RFs from individuals of the same species were more similar to each other than to those from other species, regardless of plant Se content or spatial proximity. Cultivable endophytes from hyperaccumulators $S$. pinnata and A. bisulcatus were further identified and characterized. The 66 bacterial morphotypes were shown by MS MALDI-TOF Biotyper analysis and 16S rRNA gene sequencing to include strains of Bacillus, Pseudomonas, Pantoea, Staphylococcus, Paenibacillus, Advenella, Arthrobacter, and Variovorax. Most isolates were highly resistant to selenate and selenite (up to $200 \mathrm{mM}$ ) and all could reduce selenite to red elemental Se, reduce nitrite and produce siderophores. Seven isolates were selected for plant inoculation and found to have plant growth promoting properties, both in pure culture and when co-cultivated with crop species Brassica juncea (Brassicaceae) or $M$. sativa. There were no effects on plant Se accumulation. We conclude that Se hyperaccumulators harbor an endophytic bacterial community in their natural seleniferous habitat that is equally diverse to that of comparable non-accumulators. The hyperaccumulator endophytes are characterized by high Se resistance, capacity to produce elemental Se and plant growth promoting properties.

Keywords: selenium, hyperaccumulator, endophyte, bacteria, phytoremediation, T-RFLP, microbial diversity

\section{INTRODUCTION}

Endophytic and rhizospheric microorganisms play an important role in plant physiology, including nutrient acquisition and abiotic and biotic stress resistance (Weyens et al., 2013). Endophytic microbes may colonize the interior of any plant part, including the root, stem, leaves, flowers and seeds (Jha et al., 2013). The highest densities of endophytic microorganisms have been observed in the roots, decreasing from root to stem to leaves (Moore et al., 2006). Many bacterial endophytes are closely related to common soil rhizosphere bacteria such as Enterobacter, Pseudomonas, Burkholderia, Bacillus, Azospirillum, Serratia,
Stenotrophomonas, Methylobacterium, Paenibacillus, Streptomyces, Rhizobium, Rhodococcus, Arthrobacter, Variovorax, and others (Miller et al., 1998; Lodewyckx et al., 2002; Strobel et al., 2004; Guan et al., 2005; Taghavi et al., 2005; Ryan et al., 2008; Weyens et al., 2013; Croes et al., 2014). The diversity of endophytes is dependent on plant species, cultivar and probably cultivation conditions (Ulrich et al., 2008).

Rhizospheric and endophytic microorganisms form microbial communities important for plant growth and development. These bacteria can affect plant growth by different direct and indirect mechanisms (Gupta et al., 2000; Glick, 2012), including 
(1) increased mineral nutrient access or bioavailability, including nitrogen fixation; (2) repression of soil-borne pathogens (by the production of hydrogen cyanide, siderophores, antibiotics, and/or competition for nutrients); (3) improving plant stress tolerance to drought, salinity and metal toxicity; and (4) production of phytohormones such as indole-3-acetic acid (Gupta et al., 2000; Jha et al., 2013). In addition, several studies have shown that not only rhizospheric, but also endophytic bacteria have the potential to enhance the removal of soil contaminants by phytoremediation, especially organic contaminants (Germaine et al., 2003; Barac et al., 2004; Compant et al., 2005; Dowling et al., 2008; Doty et al., 2009; Taghavi et al., 2010). The positive effects of endophytes on plant growth and elemental accumulation may be utilized in various applications. Inoculation of plant species with selected endophytes may achieve higher biomass production for agricultural crops, may confer protection of these crops against pathogens or abiotic stresses, and may increase a crop's nutritional value (biofortification) and ability for environmental cleanup (phytoremediation) (Pilon-Smits, 2005).

An interesting group of plants for phytoremediation are the socalled hyperaccumulator species, which accumulate one or more inorganic, toxic elements to levels upwards of 100-fold higher than other species growing under the same conditions (Cappa and Pilon-Smits, 2014). The toxic elements As, Co, Cu, Mn, $\mathrm{Ni}, \mathrm{Pb}, \mathrm{Se}$, and $\mathrm{Zn}$ can be hyperaccumulated to $0.1-4 \%$ of dry weight, usually both in root and shoot (Cappa and Pilon-Smits, 2014). Since plants always live in close relation with microbial communities, the question may be raised how hyperaccumulation is affected by plant-associated microbes, and vice versa, how hyperaccumulation affects microbial density and composition. Plant-microbe interactions of hyperaccumulators are a relatively unexplored area (Alford et al., 2010). Studies on Nihyperaccumulation have shown that rhizosphere microorganisms affected plant gene expression, as evident from differences in shoot proteome (Farinati et al., 2009, 2011). Inoculation of hyperaccumulator Sedum alfredii with Burkholderia cepacia (Li and Wong, 2012) did not enhance plant growth or metal uptake, but enhanced metal translocation of $\mathrm{Cd}$ and $\mathrm{Zn}$ as well as metal tolerance. Thus, when bacteria are inoculated to a hyperaccumulator, plant physiology may undergo changes. Conversely, plants affect their endophytic communities. Chen et al. (2014) reported that both plant species and heavy metal pollution contributed to the shaping of the dynamic endophytic bacterial communities associated with hyperaccumulators.

Selenium hyperaccumulators were shown to contain bacterial and fungal endophytes, including Rhizobia in root nodules as well as a seed coat fungus in the legume hyperaccumulator Astragalus bisulcatus (Valdez Barillas et al., 2012). These microbes were hypothesized to be responsible for the high levels of elemental Se (up to $30 \%$ of tissue Se) observed in nodules, roots, seeds and stems of $A$. bisulcatus in the field (Lindblom et al., 2013). The high Se levels in Se hyperaccumulators may also affect the local microbial ecology in seleniferous areas. High-Se litter $(550 \mathrm{mg}$ $\mathrm{kg}^{-1} \mathrm{DW}$ ) was found to decompose faster than low-Se litter, and to harbor higher levels of culturable microbes, suggesting the presence of a community of Se-resistant microbial decomposers
(Quinn et al., 2011). On the other hand, Se was found to protect plants from Se-sensitive fungal pathogens (Hanson et al., 2003). Thus, Se hyperaccumulators may negatively affect microbial partners if these are Se sensitive, while at the same time offering an exclusive niche for Se-resistant microbial partners. This trend has also been observed for other ecological partners, including herbivores, plants and pollinators (as reviewed in Quinn et al., 2010; El-Mehdawi and Pilon-Smits, 2012).

The aims of the current study were to determine how the microbiome differs on the endophyte level between between Se hyperaccumulator species and related non-hyperaccumulator species on the same seleniferous site, and to characterize endophytic bacteria from Se hyperaccumulators with respect to Serelated properties and plant growth promoting properties. The significance of these studies is two-fold. They are among the first to characterize the endophytic microbiomes of plants that hyperaccumulate extraordinary levels of toxic elements. In addition, microbes found to have extreme Se resistance or Se metabolic properties, or plant growth promoting properties, may have applications in industry and agriculture. Isolated microbes with high Se tolerance and ability to produce elemental Se may for instance be used for wastewater treatment and/or the production of Se nanoparticles (Staicu et al., 2015). Microbes that boost plant growth and/or plant Se tolerance and accumulation may benefit the practices of Se phytoremediation and Se biofortification, which would have substantial significance, since both Se toxicity and Se deficiency are serious problems worldwide (Zhu et al., 2009; Bãnuelos et al., 2011).

\section{MATERIALS AND METHODS COLLECTION OF PLANT MATERIAL}

Seeds of Medicago sativa were obtained from a local nursery. Brassica juncea seeds were obtained from a USDA plant introduction station as described earlier (Harris et al., 2014).

Hyperaccumulators Astragalus bisulcatus (Hook) A. Gray and Stanleya pinnata (Pursh) Britton plants (roots, stems, leaves) were collected in the summer (August) at Pineridge Natural Area, a seleniferous site west of Fort Collins, CO, USA (Figure 1). This site has been described before (Galeas et al., 2007, 2008). Collected plants were labeled Ab4, Ab5, Ab10, Sp5, Sp14, and Sp30. As non-hyperaccumalating controls, plants (roots, stems, leaves) of Medicago sativa L. (samples Ms25, Ms26) and Physaria bellii G. Mulligan (samples Pb22, $\mathrm{Pb} 23, \mathrm{~Pb} 24)$ were collected at the same site. Part of the leaf material was used for total Se concentration measurement (as described below); the rest of the plant material was used for metagenomic studies and isolation of endophytic bacteria. This plant material was stored overnight at $4^{\circ} \mathrm{C}$ in sterile $10 \mathrm{mM}$ $\mathrm{MgSO}_{4}$.

\section{MEASUREMENT OF TOTAL SE CONCENTRATIONS}

The concentration of total Se was measured using inductively coupled plasma atomic emission spectrometry (ICP-AES) according to Fassel (1978). The leaves of collected plants were rinsed with distilled water and dried for $48 \mathrm{~h}$ at $55^{\circ} \mathrm{C}$. Hundred micro gram of samples were digested in nitric acid as described by Zarcinas et al. (1987). 


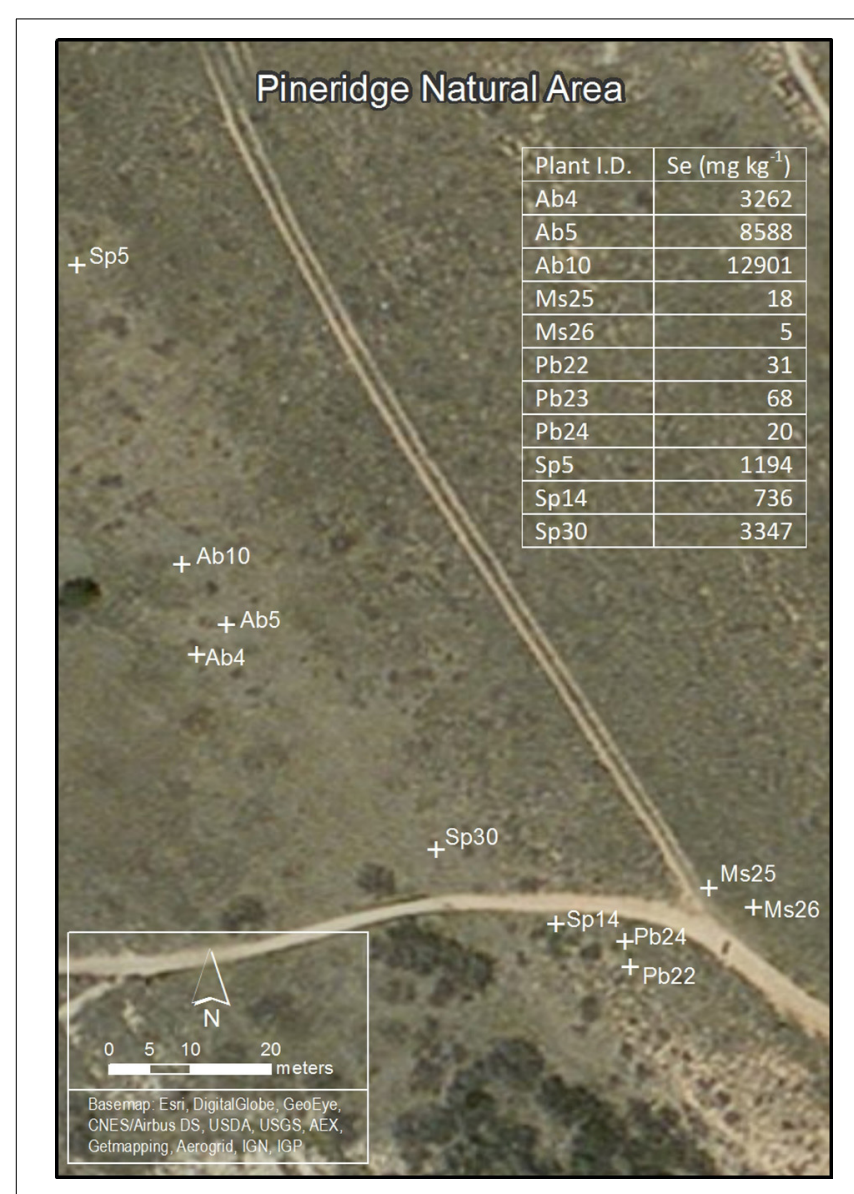

FIGURE 1 | Map of Pineridge Natural Area, the seleniferous site west of Fort Collins, CO, USA where plants were sampled for T-RFLP analysis. Ab4, Ab5, Ab10-three individual plants of Astragalus bisulcatus (hyperaccumulator); Sp5, Sp14, Sp30-three individual plants of Stanleya pinnata (hyperaccumulator); Ms25, Ms26-two individual plants of Medicago sativa (non-hyperaccumulator); Pb22, Pb23, Pb24-three individual plants of Physaria bellii (non-hyperaccumulator). The table insert lists the leaf Se concentration for every plant sampled.

\section{STERILIZATION OF THE PLANT SURFACE}

Plant material was surface-sterilized for 15 min slightly shaken in $2 \%$ active hypochlorite (household bleach, $4 \times$ dilution) containing $0.5 \mathrm{ml} \mathrm{L}^{-1}$ Tween 20 . Three wash steps with sterile distilled water were performed. A sample of the water from the last wash step was streaked on solid Luria Bertani (LB) media to verify sterility.

\section{ISOLATION OF METAGENOMIC DNA AND T-RFLP}

For endophyte comparative community diversity analysis, surface-sterilized plant material was homogenized under sterile conditions using liquid nitrogen, mortar and pestle. For each plant, equal weight samples of disintegrated roots, stems and leaves were combined into one tube and deep frozen. The metagenomic DNA (DNA of the plant body, containing a plant nuclear, plastid and mitochondrial DNA, as well as endophytic bacterial and fungal DNA) was isolated with the DNeasy Plant Mini Kit (Qiagen, USA). Then, part of the gene encoding for $16 \mathrm{~S}$ rRNA was amplified with primers 26F-FAM (5' labeled with 6-karboxyfluorescein) and 1114R (26F-FAM 5' - AGA GTT TGA TCM TGG CTC A-3', 1114R 5'- GGG TYK CGC TCG TTR-3') following a program of $95^{\circ} \mathrm{C}$ for $2 \mathrm{~min}$, then 35 cycles of $95^{\circ} \mathrm{C}$ for $20 \mathrm{~s}, 63^{\circ} \mathrm{C}$ for $30 \mathrm{~s}$, and $70^{\circ} \mathrm{C}$ for $30 \mathrm{~s}$, and final extension at $70^{\circ} \mathrm{C}$ for $7 \mathrm{~min}$. The $50-\mu \mathrm{L}$ reaction mixtures contained template DNA, 5 pmol of each primer (Generi Biotech, Czech Republic), $5 \mathrm{nmol}$ deoxynucleotide triphosphates (dNTPs), $2.5 \mu \mathrm{g}$ bovine serum albumin (BSA), and 0.5 U Novagen ${ }^{\circledR}$ KOD Hot Start polymerase with the corresponding buffer (Merck, Germany). Further, a reconditioning step was performed. Here $5-\mu \mathrm{L}$ aliquots of the initial PCR product were transferred to new reaction mixtures and amplified for three cycles under the same PCR conditions. PCR products were purified with the PureLink ${ }^{\circledR}$ PCR Purification Kit (Invitrogen, USA). Fifty nano gram of DNA were digested with $H$ haI restriction endonuclease following a reaction mixture of template DNA, $4 \mathrm{U}$ HhaI (New England BioLabs, UK), $0.3 \mu \mathrm{L}$ BSA (New England BioLabs, UK) and $2 \mu \mathrm{L}$ corresponding buffer. The reaction mixture was incubated $60 \mathrm{~min}$ at $37^{\circ} \mathrm{C}$. After DNA cleavage, $1.5 \mu \mathrm{L}$ of sodium acetate together with $1 \mu \mathrm{L}$ of glycogen (molecular biology grade) and $47 \mu \mathrm{L}$ of $98 \%$ ethanol were added. The mixture was incubated $20 \mathrm{~min}$ at $-80^{\circ} \mathrm{C}$ to precipitate the DNA. The mixture was centrifuged for $10 \mathrm{~min}$ at $4^{\circ} \mathrm{C}$ at maximum speed. The DNA pellet was washed using first $1 \mathrm{~mL}$ of cooled $70 \%$ ethanol and a second wash was performed with $98 \%$ ethanol.

Analysis of terminal restriction fragment length polymorphism (T-RFLP) was performed by fragmentation analysis. Aliquots of the restricted fragments were mixed with an internal size standard (LIZ600, Applied Biosystems) and separated on an automated genetic analyzer using fragmentation module (Applied Biosystems 3500 Genetic Analyzer). The data were processed in GeneMapper 5.0 software (Applied Biosystems, Foster City, CA) in which peak detection was done by the default settings (Local Southern method with Peak Amplitude Threshold of 50 fluorescence units, no smoothing and Baseline Window of 51 points). Peak tables from all spectra were exported to MS Excel, where the peak positions were rounded to the closest integer and samples were normalized by dividing each peak's fluorescence intensity by total signal intensity of the corresponding sample. All terminal restriction fragments (T-RFs) with size lower $50 \mathrm{bp}$ and intensities below 0.01 were excluded to evaluate the differences in bacterial diversity of hyperaccumulators and non-hyperaccumulator plants.

\section{PARSIMONY ANALYSIS TO COMPARE RELATEDNESS OF ENDOPHYTE MICROBIOME SAMPLES}

Equally weighted parsimony tree searches were conducted using Paup* (ver. 4.0b10; Swofford, 2001). Up to 10 trees were held within each of the 2000 random addition tree-bisectionreconnection (TBR) branch swapping searches. Branch support was determined using parsimony jackknife (Farris et al., 1996); analyses were conducted with the removal probability set to approximately $\mathrm{e}^{-1}(0.37)$.

\section{ISOLATION OF ENDOPHYTIC BACTERIA}

Disintegration of surface-sterile plant material (separate roots, stems and leaves) was carried out at room temperature in $1.5 \mathrm{~mL}$ microcentrifuge tubes using a plastic micropestle. 
Samples were homogenized in sterile $10 \mathrm{mM} \mathrm{MgSO}_{4}$ (dilution $\left.10^{-1}\right)$. Hundred micro liter of dilutions of $10^{-1}, 10^{-3}$ and $10^{-5}$ in $10 \mathrm{mM} \mathrm{MgSO}_{4}$ were spread out on Petri dishes with solid half-strength LB medium ( $1 / 2 \mathrm{LB}), 1 / 2 \mathrm{LB}$ with plant extract (preparation of plant extract described below), and on $1 / 2$ MS plant cultivation media (Murashige and Skoog, 1962). Bacteria were cultivated at room temperature for 7 days. For each plant species, microorganisms displaying different morphologies were re-streaked on new plates to obtain axenic monocultures.

\section{PREPARATION OF PLANT EXTRACT}

Plant extracts of $A$. bisulcatus and S. pinnata were prepared from $2.8 \mathrm{~g}$ of fresh leaf material by disintegration with mortar and pestle and adding $40 \mathrm{~mL}$ of warm water $\left(\sim 40^{\circ} \mathrm{C}\right)$. This mixture was centrifuged for $5 \mathrm{~min}$ at $4000 \times \mathrm{g}$ and the supernatant was filter sterilized $(0.22 \mu \mathrm{m}$ pore size $)$. The obtained volume of each plant extract was $16 \mathrm{~mL}$. The ratio of this plant material used in the cultivation medium represented 1:50 (v/v).

\section{MORPHOLOGICAL ANALYSIS OF ISOLATES}

Isolates were characterized according to their macroscopic and microscopic morphology (form/elevation/margin/surface/color of the colony, bacilli/cocci/gram staining). Detrended canonical correspondence analysis (DCA) was applied to explore the correlation between morphological characteristics of endophytic isolates using CANOCO 5 according to ter Braak and Šmilauer (1998). Plant organs (root, stems, and leaves) from which the isolates were isolated were used as supplementary explanatory variables.

\section{IDENTIFICATION OF ENDOPHYTIC BACTERIA USING MALDI-TOF MS}

Isolates were identified via the method of matrix-assisted laser desorption ionization - time of flight (MALDI-TOF) mass spectrometry and MALDI Biotyper. The Bruker Biflex IV MALDITOF spectrometer (equipped with a UV nitrogen laser [337 nm] and a dual microchannel microplate detector) and MALDI Biotyper 2.0 software (Bruker Daltonics, Bremen, Germany) were used. Samples for the analysis were prepared according to manufacturers' recommendations: after $24-48 \mathrm{~h}$ of cultivation of an isolate on LB medium (Oxoid Ltd., United Kingdom) at $28^{\circ} \mathrm{C}$, a single colony was transferred with a sterile tip onto the MALDI target in triplicates, drizzled with $1 \mu \mathrm{L}$ of a saturated solution of $\alpha$-cyano-4-hydroxycinnamic acid (Sigma-Aldrich) in organic solution (50\% acetonitrile, $2.5 \%$ trifluoroacetic acid), and directly screened. The measurement of the spectra was performed as previously described (Uhlik et al., 2011). The matching of unknown spectra to the reference database is based on dedicated score (point) values. This value is used for calculating the final score, according to which the identification results are evaluated as follows: if the logarithmic value of the final score is between 2.3 and 3 , the isolate is identified at the level of species; for values between 2 and 2.3, the identification is secure at the level of genus; for values between 1.7 and 2, the identification at the level of genus is probable; and for values lower than 1.7, the identification is not successful.

\section{IDENTIFICATION OF ENDOPHYTIC BACTERIA USING 16S rRNA GENE SEOUENCING}

Several bacterial isolates were identified using 16S rRNA gene sequence analysis. A colony PCR was performed to amplify part of the gene encoding $16 \mathrm{~S}$ rRNA with primers $8 \mathrm{~F}\left(5^{\prime}\right.$ - AGA GTT TGA TCC TGG CTC AG- 3', Lane, 1991) and 926R (5' - CCG TCA ATT CCT TTR AGT TT- 3', Amann et al., 1995) following a program of $96^{\circ} \mathrm{C}$ for $3 \mathrm{~min}, 10$ cycles of $96^{\circ} \mathrm{C}$ for $45 \mathrm{~s}, 50^{\circ} \mathrm{C}$ for $30 \mathrm{~s}$ and $72^{\circ} \mathrm{C}$ for $2 \mathrm{~min}, 25 \mathrm{cycles}$ of $96^{\circ} \mathrm{C}$ for $20 \mathrm{~s}, 50^{\circ} \mathrm{C}$ for $30 \mathrm{~s}$ and $72^{\circ} \mathrm{C}$ for $2 \mathrm{~min}$. The $25-\mu \mathrm{L}$ reaction mixtures contained the template DNA, 5 pmol of each primer (Generi Biotech, Czech Republic), 5 nmol deoxynucleotide triphosphates (dNTPs) (New England Biolabs), $2.5 \mu \mathrm{g}$ bovine serum albumin (BSA) (New England Biolabs), and 0.5 U Taq DNA polymerase with the corresponding buffer (New England Biolabs). PCR products were purified with the QIAquick PCR purification kit (Qiagen, Germany). Purified products were sent to University of Chicago Research Center DNA Sequencing Facility, USA. Classification was performed by means of Ribosomal Database Project (RDP) Classifier (14) at an $80 \%$ confidence threshold.

\section{FUNCTIONAL CHARACTERIZATION OF ENDOPHYTIC ISOLATES}

Selenate $\left(\mathrm{SeO}_{4}^{2-}\right)$ and selenite $\left(\mathrm{SeO}_{3}^{2-}\right)$ resistance and reduction abilities were tested on solid LB media spiked with $0.1 \mathrm{mM}, 1 \mathrm{mM}$, $10 \mathrm{mM}, 100 \mathrm{mM}$ and $200 \mathrm{mM} \mathrm{Na}_{2} \mathrm{SeO}_{4}$ or $\mathrm{Na}_{2} \mathrm{SeO}_{3}$, respectively. The cultivation of bacteria was performed at $28^{\circ} \mathrm{C}$ overnight, after which growth and color were scored; in absence of good growth, additional monitoring was performed after 3 days. Growth was analyzed qualitatively; the ability to produce red elemental Se was scored visually as red coloration. To analyze the effect of nitrate on selenite reduction and resistance, the bacteria were also grown on $10 \mathrm{mM} \mathrm{Na}_{2} \mathrm{SeO}_{3}$ supplemented with $100 \mathrm{mM} \mathrm{KNO}_{3}$, and red color formation, indicative for Se reduction, was scored.

Nitrite reduction ability was tested in liquid media containing $0.1 \%$ potassium nitrite (medium composition: beef (meat) extract $3.0 \mathrm{~g} \mathrm{~L}^{-1}$, gelatin peptone $5.0 \mathrm{~g} \mathrm{~L}^{-1}$, potassium nitrite $\left.\left(\mathrm{KNO}_{2}\right) 1.0 \mathrm{~g} \mathrm{~L}^{-1}\right)$. The cultivation of bacteria was performed at $28^{\circ} \mathrm{C}(130 \mathrm{rpm})$. Every $24 \mathrm{~h}$ for 6 days in row, $1 \mathrm{~mL}$ of the culture was sampled, centrifuged and an aliquot was tested for nitrite presence according to the Griess reaction (Green et al., 1982). If nitrite was present, the reaction mixture turned pink, purple or red (depending on the amount of nitrite present). Reduction of potassium nitrite was shown by a transparent color of the mixture.

Siderophore production of isolates was tested on Chromazurol-S (CAS) agar media as described by Shin et al. (2001). Isolates were cultivated for $120 \mathrm{~h}$ at $28^{\circ} \mathrm{C}$. Siderophoreproducing strains formed a halo zone around the colony. Phosphate solubilization, acetoin production, acid production (methyl red), indole acetic acid (IAA) production, and chitinate and protease activity were analyzed as described by Weyens et al. (2013).

\section{PLANT INOCULATION WITH SELECTED BACTERIAL ENDOPHYTES}

Medicago sativa and Brassica juncea (L.) plants were grown from surface-sterilized seeds on soil collected from Pineridge Natural Area (described by Galeas et al., 2007). After collection, the soil 
was homogenized and mixed with Turface ${ }^{\circledR}$ in a 2:1 soil: Turface ${ }^{\circledR}$ ratio. Polypropylene (Magenta) boxes were then filled to a height of $2 \mathrm{~cm}$ with the mixture. The Magenta boxes were closed and autoclaved for $40 \mathrm{~min}$. Seeds were surface-sterilized by rinsing for $30 \mathrm{~min}$ in $15 \%$ household bleach $(1.5 \% \mathrm{NaClO})$ followed by 5 rinses for $5 \mathrm{~min}$ each in sterile water, and sown in the Magenta boxes at a density of 3 seeds per box. One week after germination, seedlings were thinned to one plant per box and inoculated with endophytic bacteria as follows. For M. sativa, three isolates were used that originated from $A$. bisulcatus (\#8, 31, and 32, see Table 2 for more information). In addition to the single-strain inoculants, a fourth treatment consisted of a mixture of all three isolates, and a fifth control treatment received no inoculum. For $B$. juncea, four isolates were used that originated from $S$. pinnata (\#54, 64, 71, and 77, see Table 2 for more information). These were inoculated individually as well as in a mix of all four, and there was an uninoculated control treatment. The bacteria were grown in half-strength $\mathrm{LB}$ for $24 \mathrm{~h}$ at $25^{\circ} \mathrm{C}$, harvested by centrifugation and resuspended in $10 \mathrm{mM} \mathrm{MgSO}_{4}$ to an $\mathrm{OD}_{600}$ of 1.0. One $\mathrm{mL}$ of inoculum was delivered using a pipette to the base of the seedlings; the controls received $1 \mathrm{~mL}$ of $10 \mathrm{mM} \mathrm{MgSO}_{4}$. The plants were allowed to grow for 6 weeks. The boxes were watered with autoclaved water every 2 weeks (twice total). The plants were then harvested, separating the root and shoot. Small shoot and root samples from each plant were placed in $10 \mathrm{mM}$ $\mathrm{MgSO}_{4}$ for re-isolation of bacterial endophytes, to verify successful inoculation. These were ground using sterile micropestles in microcentrifuge tubes, and $100 \mu \mathrm{L}$ of the extract was streaked onto LB agar plates, which were monitored after $24 \mathrm{~h}$ and compared visually with the inoculum. The remainder of the root and shoot material was dried and weighed. Root and shoot samples were digested in nitric acid (Zarcinas et al., 1987) and analyzed for Se concentration using inductively coupled plasma optical emission spectrometry (ICP-OES) according to Fassel (1978) and as described by Harris et al. (2014).

\section{RESULTS \\ ANALYSIS OF BACTERIAL ENDOPHYTES USING A METAGENOMIC APPROACH}

Plant leaves, stems and roots of three Se hyperaccumulator (HA) species Astragalus bisulcatus (Fabaceae) and Stanleya pinnata (Brassicaceae) and related non-hyperaccumulator (non-HA) species from the same site, Medicago sativa (Fabaceae) and Physaria bellii (Brassicaceae) were collected in triplicate and examined for microbial endophytes. To determine if the diversity of bacterial endophytes can be correlated to the Se content or geographic location of the collected plants, Se concentration in leaves was determined, and the locations of the sampled plants was mapped (Figure 1). As expected, the HA species S. pinnata and A. bisulcatus contained much higher Se levels (averaging around 1700 and $8000 \mathrm{mg} \mathrm{kg}^{-1} \mathrm{DW}$, respectively) than the non-HA species (averaging around 20 and $40 \mathrm{mg} \mathrm{kg}^{-1} \mathrm{DW}$ ).

To examine the diversity of the endophytic bacteria of each individual plant, T-RFLP analysis was performed on pooled root, stem and leaf DNA. The T-RF pattern may serve as a proxy for microbial diversity, although the T-RFs can contain one or more bacterial species. The used primers (26F-FAM and 1114R) amplified also mitochondrial DNA, which resulted in a T-RF of 220-221 bp after the restriction digest. The number of T-RFs (Supplemental Table 1) obtained per individual plant was not significantly different between the four plant species (ANOVA, $p>0.05$ ), and was $12.5,16.7,17.3$, and 18.7 for M. sativa, S. pinnata, $P$. bellii, and A. bisulcatus, respectively. Some apparent differences between HA and non-HA species are that both non-HA species showed an abundance of peaks of $<100 \mathrm{bp}$ length, while those peaks were not present in HA (Figure 2). Both HA species showed an apparent enrichment of terminal restriction fragments of sizes $\sim 200 \mathrm{bp}, \sim 380 \mathrm{bp}$ and in the case of $A$. bisulcatus also $423 \mathrm{bp}$ (Figure 2). Additionally, the T-RF profiles from members of the Brassicaceae (HA and non-HA) contained terminal fragments of $559 \mathrm{bp}$ and $587 \mathrm{bp}$, whereas these fragments were not present in the profiles of the two members of the Fabaceae family.

To compare the microbiomes of the various plant samples in more detail, a matrix (Supplemental Table 1) scoring the presence or absence of each T-RF in each individual plant was used to create a parsimony tree using PAUP software. A total of 341 characters were analyzed. Seven characters were constant, 64 variable characters were parsimony uninformative and 270 were parsimony informative. As shown in Figure 3, microbiomes obtained from individuals belonging to a certain plant species tended to be similar to each other. This was true even when these individuals were growing at physically remote locations (Figure 1). Beyond the plant species level, there was no apparent similarity between T-RFs patterns, nor did T-RFs patterns cluster according to plant Se content (Figures 1, 3).

\section{ISOLATION OF BACTERIAL ENDOPHYTES AND THEIR IDENTIFICATION}

To further investigate the endophytic microbiomes of Se HA species, we cultured endophytic bacteria from A. bisulcatus and S. pinnata. Three individuals from each species were sampled, and Se levels examined from roots, stems and leaves. For A. bisulcatus plant 1 the Se levels were: 1606, 4752, and $8834 \mathrm{mg} \mathrm{kg}^{-1} \mathrm{DW}$, respectively. For plant 2 the root, stem and leaf Se levels were 813, 9158, and 13,685 $\mathrm{mg} \mathrm{kg}^{-1} \mathrm{DW}$, and for plant 3 they were 694, 5658 , and $4732 \mathrm{mg} \mathrm{kg}^{-1} \mathrm{DW}$, respectively. The root, stem and leaf Se levels for S. pinnata plant 1 were 417, 1655, and $277 \mathrm{mg} \mathrm{kg}^{-1}$ DW, respectively; for plant 2 they were 847, 3384, and $3713 \mathrm{mg}$ $\mathrm{kg}^{-1} \mathrm{DW}$, respectively, and for plant 3 they were 944, 583, and $2406 \mathrm{mg} \mathrm{kg}^{-1} \mathrm{DW}$, respectively.

Astragalus bisulcatus and S. pinnata endophytic bacteria were isolated separately from stems, leaves and roots. Most bacteria were isolated from roots, followed by leaves, then stems. In total, 54 and 50 isolates were obtained from A. bisulcatus and S. pinnata, respectively. A. bisulcatus stems, leaves and roots yielded 4, 18 , and 32 isolates, while 8,8 , and 34 isolates were obtained from S. pinnata stems, leaves and roots, respectively.

Macroscopic and microscopic characterization of individual isolates was performed (Supplemental Table 2) and detrended canonical correspondence analysis (CANOCO) used to explore any correlation between endophytic isolates composition and the plant part from which they were isolated. The ordination diagrams (Figure 4) can be interpreted by the following rule: spatial proximity in the graph reflects similarity. In this manner, similarity and/or correlation among isolates and characteristics can 


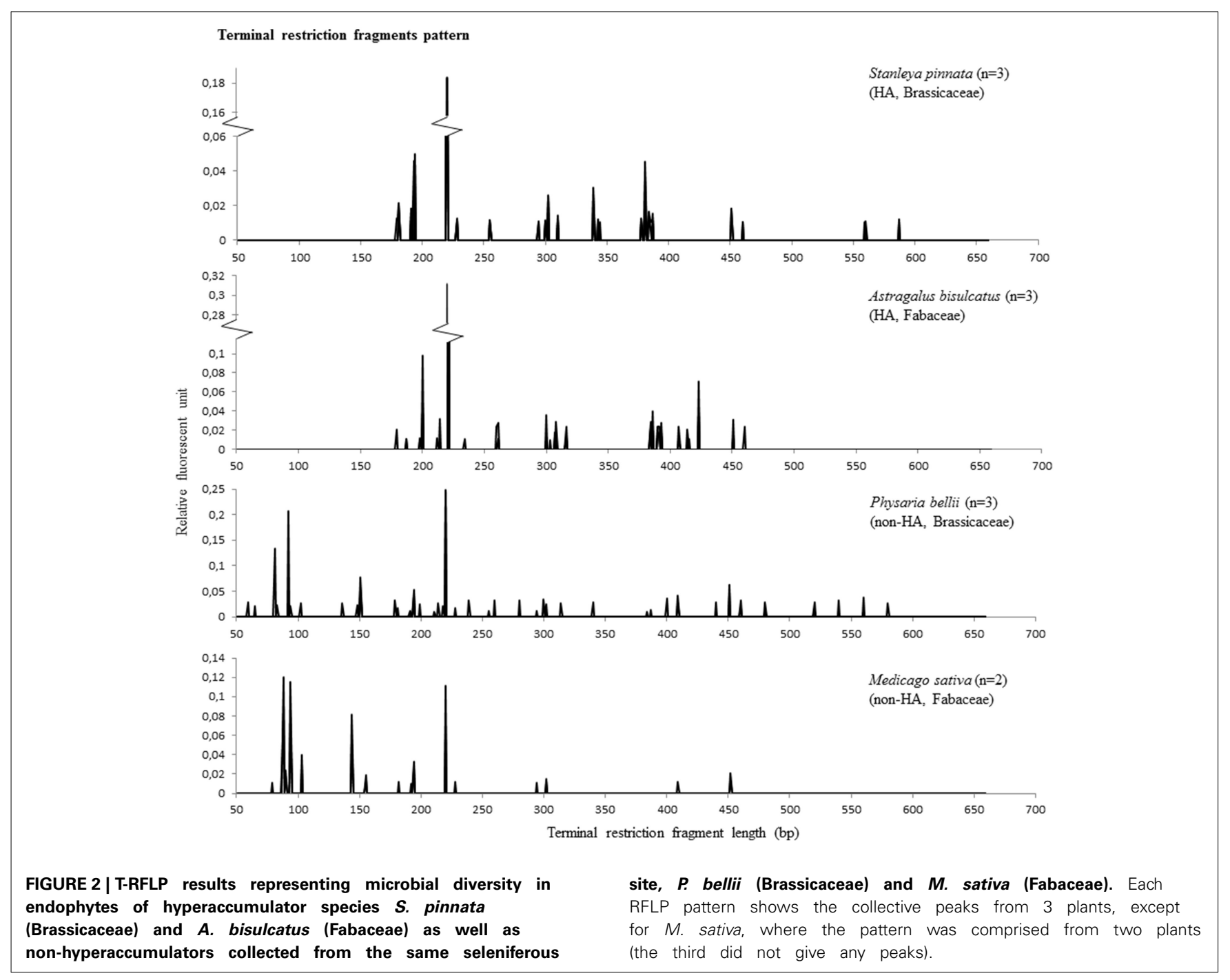

be estimated. Two ordination axes explained 44 and $48 \%$ of total variation, while plant organs accounted for only 5 and $6 \%$ of variation, respectively. As shown in Figure 4, the macroscopic and microscopic characteristics were not dependent on plant organ for A. bisulcatus. In the case of S. pinnata, however, isolates from stems had different characteristics than isolates from leaves and roots.

The endophytic isolates were identified via the method of matrix-assisted laser desorption ionization time of flight (MALDI-TOF) mass spectrometry and MALDI Biotyper. Fifty four percent of isolates from A. bisulcatus were identified with highly probable species identification, $28 \%$ with secure genus identification, probable species identification, $15 \%$ with probable genus identification and $3 \%$ were not identified. In the case of $S$. pinnata, $42 \%$ of isolates were identified with highly probable species identification, $28 \%$ with secure genus identification, probable species identification, $26 \%$ with probable genus identification and $4 \%$ were not identified. Five isolates were also identified using the analysis of $16 \mathrm{~S}$ rRNA gene sequence. As shown in Table 1, Bacillus was the bacterial genus most frequently isolated from the HA plants. Other abundant identified bacterial genera were Pantoea, Pseudomonas and Staphylococcus; in additional there were isolates of Paenibacillus, Advenella, Arthrobacter, and Variovorax.

\section{FUNCTIONAL CHARACTERIZATION OF ISOLATED BACTERIAL ENDOPHYTES}

All isolated, purified cultivable strains that were morphologically different (judged from DCA and from the identification using MALDI-TOF MS) were qualitatively screened for their abilities to grow on and/or reduce selenite and selenate, to reduce selenite in the presence of nitrate, to reduce nitrite and to produce siderophores (Table 2). Isolates were grown on LB media containing 0-200 $\mathrm{mM} \mathrm{SeO}_{3}^{2-}$ or $\mathrm{SeO}_{4}^{2-}$. All isolates were able to grow on both selenite and selenate and reduced selenite to red elemental Se. None of the isolates reduced selenate to red elemental Se. The selenite resistance was scored as follows: $100 \%$ of all A. bisulcatus and of $S$. pinnata isolates grew on $0.1 \mathrm{mM}$ and $1 \mathrm{mM} \mathrm{SeO}_{3}^{2-}$, $96 \%$ of the A. bisulcatus and of S. pinnata isolates grew on $10 \mathrm{mM}$ $\mathrm{SeO}_{3}^{2-}, 75$ and $76 \%$ grew on $100 \mathrm{mM} \mathrm{SeO}_{3}^{2-}$, and 58 and $80 \%$ 
on $200 \mathrm{mM} \mathrm{SeO}_{3}^{2-}$, respectively. On the two highest concentrations some isolates grew more slowly, needing 3 days instead of one to fully grow. The resistance to selenate was as follows: $96 \%$ of $A$. bisulcatus and $88 \%$ of $S$. pinnata isolates grew on $0.1 \mathrm{mM}$

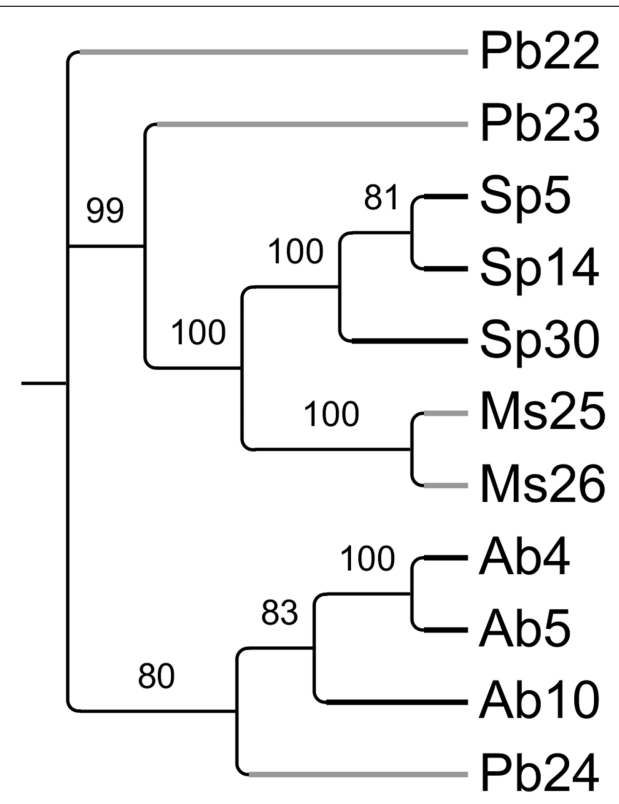

FIGURE 3 | Most parsimonious tree reflecting similarity in endophyte diversity between the sampled plants (PAUP, obtained from T-RFLP data matrix listed in Supplemental Table 1). Values above the branches represent parsimony jackknife support values $\geq 50 \%$. Physaria bellii 22 was used to root the tree. Black branches represent hyperaccumulators and gray branches represent non-hyperaccumulators.
$\mathrm{SeO}_{4}^{2-}$, while 100 and $96 \%$ grew on $1 \mathrm{mM} \mathrm{SeO}_{4}^{2-}, 100$ and $96 \%$ on $10 \mathrm{mM} \mathrm{SeO}_{4}^{2-}, 100$ and $100 \%$ on $100 \mathrm{mM} \mathrm{SeO}_{4}^{2-}$, and 100 and $96 \%$ on $200 \mathrm{mM} \mathrm{SeO}_{4}^{2-}$, respectively. Thus, the resistance of the isolates was generally higher to selenate than to selenite. The same trend was apparent when the selenite and selenate resistance of endophytes isolated from different hosts and organs were given a score (1-5) and the scores were averaged by genus (Table 2, Figure 5). Selenium resistance was higher to selenate than to selenite, and strains that were more selenite-resistant were usually also more selenate-resistant. No differences in Se tolerance are apparent between isolates of A. bisulcatus or S. pinnata. Shoot endophytes from both plant species tended to be more sensitive to both selenite and selenate than root endophytes, sometimes even for isolates from the same genus (Bacillus). Comparison of the four most commonly isolated genera indicate that Bacillus is the most sensitive to selenite and selenate, while Pantoea is most resistant and Pseudomonas and Staphylococcus are intermediate in Se resistance.

Elemental Se production from $10 \mathrm{mM}$ selenite was inhibited when $100 \mathrm{mM}$ nitrate was added to the media for $20 \%$ of A. bisulcatus isolates and $60 \%$ of $S$. pinnata isolates. Growth was typically inhibited concomitantly. Variovorax sp. (A. bisulcatus, root) and Bacillus atrophaeus (S. pinnata, stem) were particularly sensitive to this inhibition (Table 2).

All tested isolates were able to reduce nitrite. Some of the isolates had completely reduced the supplied nitrite in 2 days, while some needed more than 6 days (Table 2). No apparent differences were found between isolates of $A$. bisulcatus or S. pinnata in this respect. The shoot endophytes from both species tended to reduce nitrite faster than the root endophytes. Among isolates reducing all nitrite in 2 days were Bacillus atrophaeus (S. pinnata, leaf), Pantoea agglomerans (S. pinnata, root) and Pseudomonas koreensis

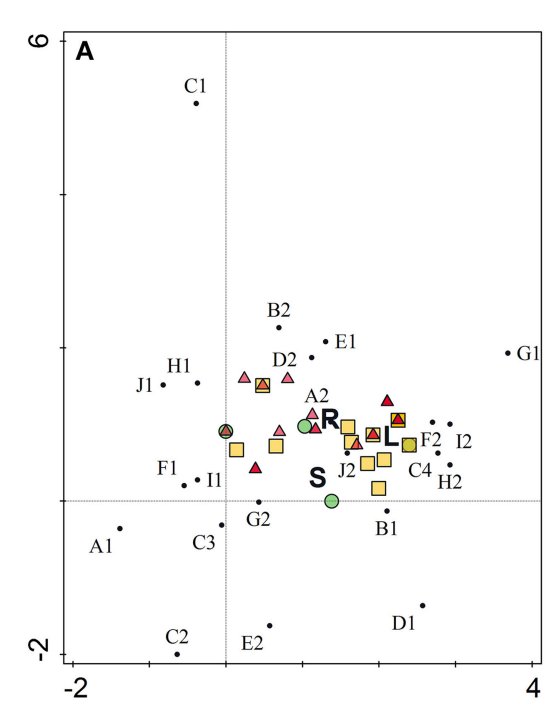

FIGURE 4 | Ordination diagram as an output of detrended canonical correspondence analysis of morphological characteristics of endophytic isolates from hyperaccumulators Astragalus bisulcatus (A) and Stanleya pinnata (B). $X$ axis, DCA axis1; $Y$ axis, DCA axis2. Organ variables are represented by letters ( $R$, root; $S$, stem; $L$, leaf), isolates by colored circles (isolates from stems), triangles (isolates from roots) and squares (isolates

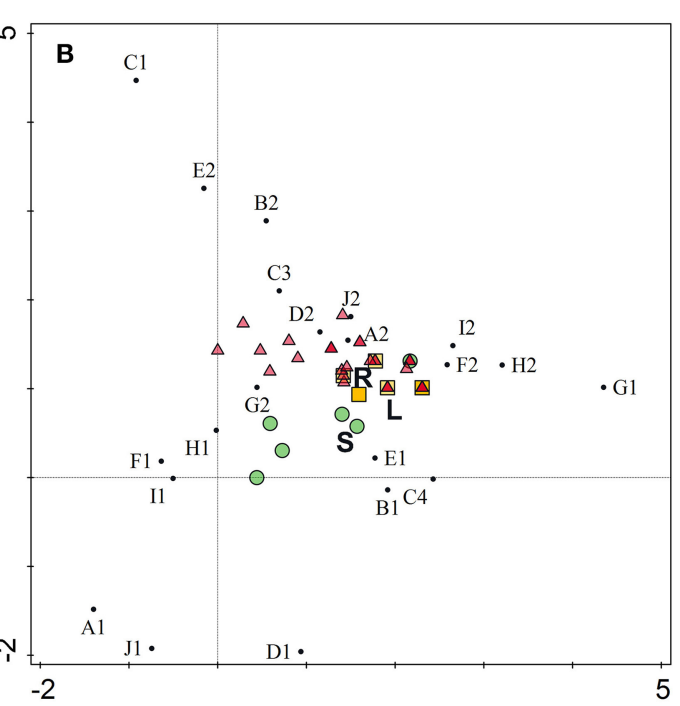

from leaves) and characteristics by small black circles. A1 (cocci), A2 (rods), B1 (Gram-positive), B2 (Gram-negative), C1 (yellow), C2 (yellowish), C3 (creamy), C4 (white), D1 (colonies getting brown with time), D2 (colonies do not get brown with time), E1 (circular colony form), E2 (irregular form), F1 (entire margin), F2 (undulate margin), G1 (flat colony), G2 (raised colony), H1 (smooth), H2 (rough), I1 (shiny), I2 (dry), J1 (punctiform), J2 (regular size). 
Table 1 | Bacterial isolates from hyperaccumulators Astragalus bisulcatus and Stanleya pinnata.

\begin{tabular}{|c|c|c|c|c|c|c|c|c|}
\hline \multicolumn{3}{|l|}{ Stems } & \multicolumn{3}{|l|}{ Leaves } & \multicolumn{3}{|c|}{ Roots } \\
\hline Bacillus atrophaeus & +++ & 2 & Bacillus atrophaeus & +++ & 7 & Bacillus atrophaeus & +++ & 7 \\
\hline Paenibacillus illinoisensis & ++ & 1 & Bacillus atrophaeus & ++ & 4 & Bacillus atrophaeus & ++ & 2 \\
\hline \multirow[t]{6}{*}{ Pseudomonas sp. } & + & 1 & Bacillus cereus & ++ & 1 & Bacillus sp. & + & 1 \\
\hline & & & Pantoea agglomerans & +++ & 1 & Pantoea agglomerans & ++ & 4 \\
\hline & & & Staphylococcus epidermidis & ++ & 1 & Pseudomonas koreensis & ++ & 1 \\
\hline & & & & & & Pseudomonas sp. & + & 2 \\
\hline & & & & & & Advenella kashmirensis & $16 S^{* *}$ & 1 \\
\hline & & & & & & Variovorax sp. & + & 1 \\
\hline Staphylococcus condimenti & ++ & 1 & Bacillus atrophaeus & ++ & 2 & Bacillus atrophaeus & ++ & 5 \\
\hline Staphylococcus sp. & + & 1 & Pantoea agglomerans & +++ & 1 & Bacillus sp. & + & 6 \\
\hline Pseudomonas koreensis & ++ & 1 & & & & Pantoea agglomerans & +++ & 6 \\
\hline \multirow[t]{8}{*}{ Pseudomonas sp. } & + & 1 & & & & Pantoea agglomerans & ++ & 1 \\
\hline & & & & & & Pantoea sp. & + & 1 \\
\hline & & & & & & Pseudomonas koreensis & ++ & 3 \\
\hline & & & & & & Pseudomonas sp. & + & 2 \\
\hline & & & & & & Pseudomonas moraviensis & $16 S^{* *}$ & 1 \\
\hline & & & & & & Arthrobacter sp. & $16 S^{* *}$ & 1 \\
\hline & & & & & & Staphylococcus sp. & + & 2 \\
\hline & & & & & & $N R^{*}$ & - & 2 \\
\hline
\end{tabular}

Score +++ highly probable species identification, ++ secure genus identification, probable species identification, + probable genus identification, - not reliable identification. "NR, not reliable identification; ${ }^{* *} 16 S$, identification by analysis of $16 S$ rRNA gene sequence, \#, number of total isolates.

(S. pinnata, root). The endophytic isolates were also screened for their ability to produce siderophores. All isolates tested, from both A. bisulcatus and S. pinnata were able to produce siderophores.

\section{INOCULATION OF NON-HYPERACUMULATING PLANTS BY SELECTED ENDOPHYTES}

A selection of seven bacterial endophytes was tested for their effects on plant growth and Se accumulation from naturally seleniferous soil: Bacillus sp. (A. bisulcatus, leaf), Advenella kashmirensis (A. bisulcatus, root), Pantoea agglomerans (A. bisulcatus, root), Bacillus atrophaeus (S. pinnata, leaf), Arthrobacter sp. (S. pinnata, root), Pseudomonas moraviensis (S. pinnata, root), and Pseudomonas sp. (S. pinnata, root). These isolates were chosen based on their capacity to grow on both selenate and selenite $(10 \mathrm{mM})$, and to represent the microbial diversity and diversity in origin from roots and shoots of both HA species. For more information about the properties of the selected isolates, see Table 2. The endophytes originating from A. bisulcatus were inoculated to plants of crop species Medicago sativa from the same family (Fabaceae), while endophytes originating from $S$. pinnata were inoculated to plants of related crop species Brassica juncea. These crop species were chosen because they were not likely to already harbor these endophytes and because of the possible economic importance related to endophyte-enhanced Se uptake and growth of these plant species for biofortification or phytoremediation.

The inoculated plants of both plant species generally showed an increase in root and shoot biomass production, relative to the uninoculated controls; the effect on shoot biomass was significant for all but one inoculation treatment, while root biomass was significantly affected by two of the inoculation treatments for both species (Figures 6A,B,E,F). The positive effect of inoculation on plant growth was up to three-fold for individual isolates; there was no synergistic effect of inoculation with a mix of isolates. There were no significant differences in root or shoot Se concentration between control and inoculated plants of both plant species, although the inoculated plants on average showed lower Se levels (Figures 6C,D,G,H).

To get better insight into the mechanisms underlying the observed increase in plant biomass in the presence of these endophytic bacteria, the isolates were tested for various known plant growth promoting properties. Six out of the seven isolates tested (all except Arthrobacter sp.) showed phosphate solubilization activity, which may help plant hosts acquire this macronutrient (Qureshi et al., 2012). Five of the isolates produced acetoin (Table 3). This compound, produced by many bacteria during 


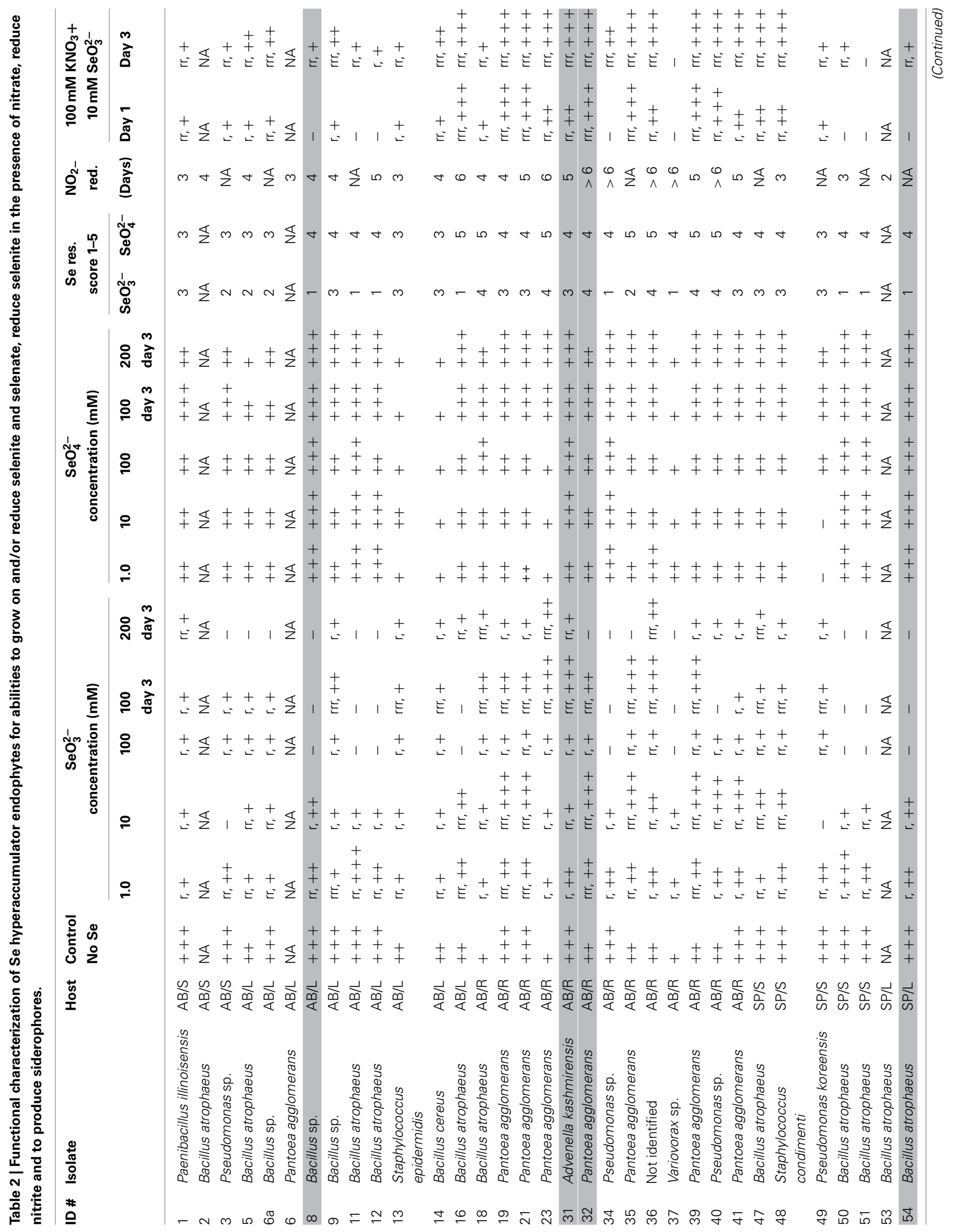




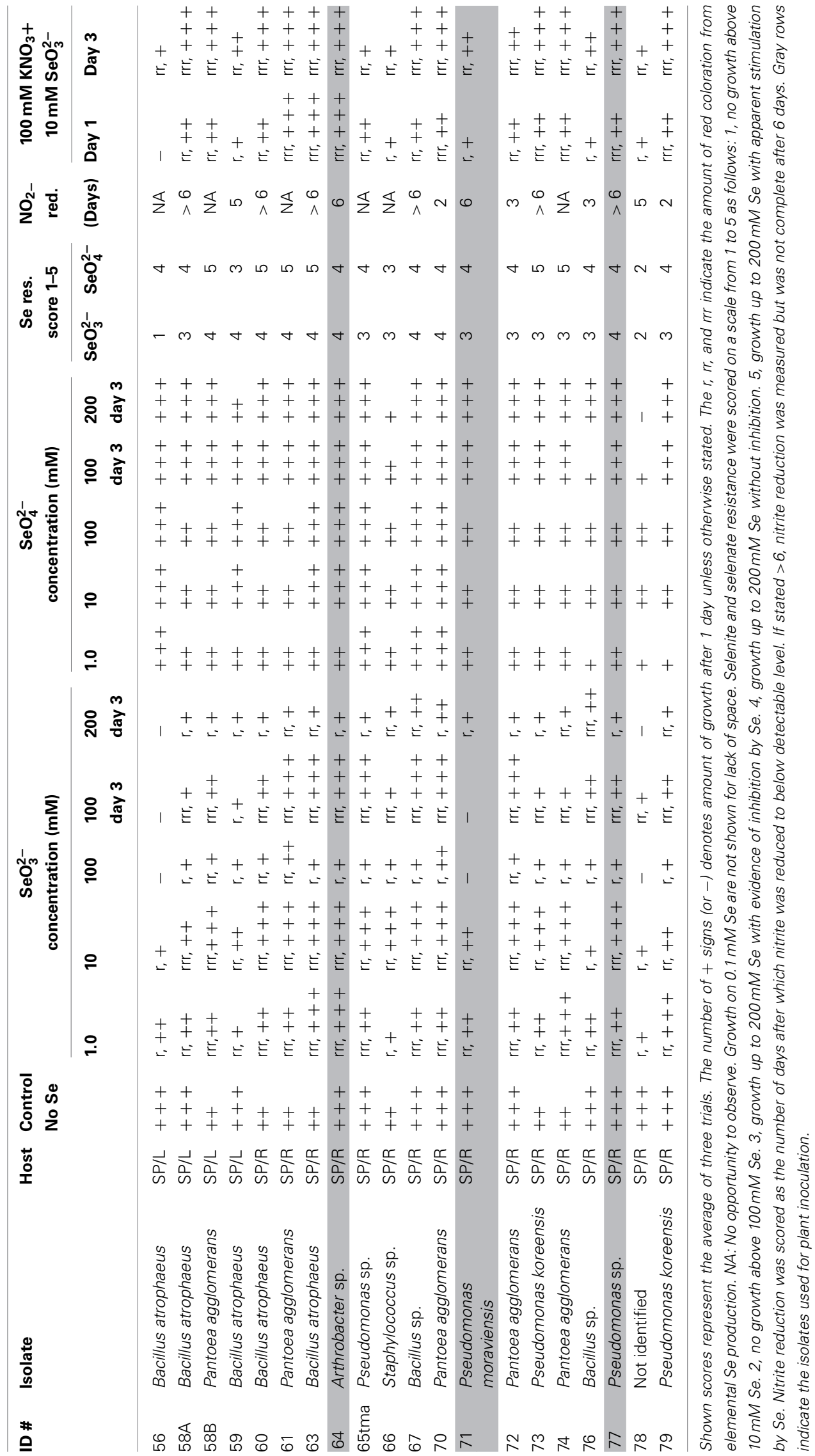




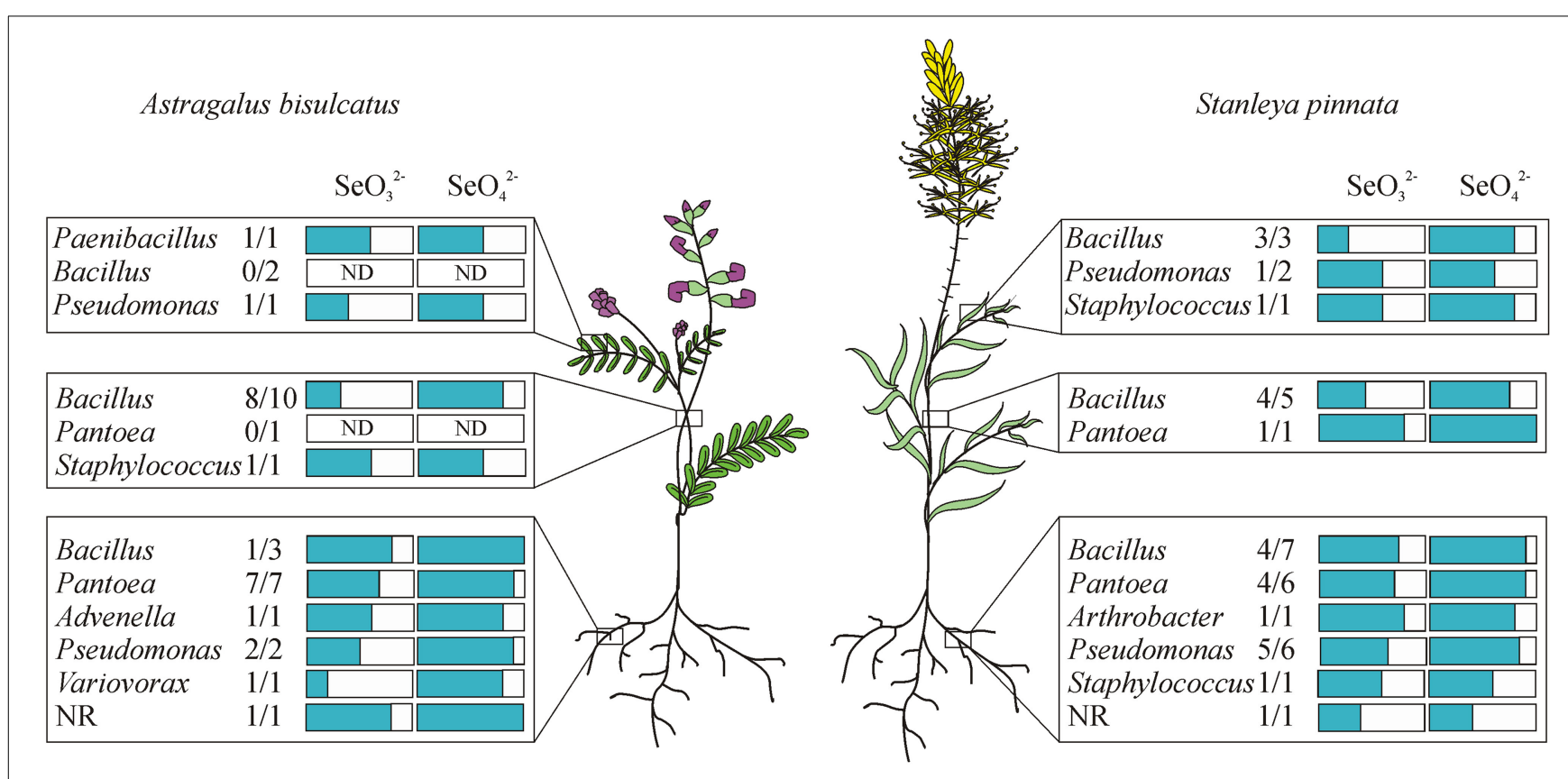

FIGURE 5 | Distribution of endophytic bacterial isolates in the hyperaccumulators Astragalus bisulcatus and Stanleya pinnata and their resistance to selenite and selenate (scored from 1 to 5). Plants were collected at the Pineridge Natural Area, a seleniferous site west of Fort Collins, CO, USA.

colony formation, has been shown to promote plant growth (Ryu et al., 2003). Furthermore, the two Pseudomonas spp. and Pantoea agglomerans produced the plant growth regulator indole acetic acid (IAA), which induces root formation and cell expansion (Bonner and Bandurski, 1952). Protease activity, a mechanism by which bacteria may help host plants defend against biotic stressors (Cho et al., 2007), was found for four of the isolates: both Bacillus species as well as A. kashmirensis and Pseudomonas sp. (Table 3). The two Bacillus atrophaeus isolates and to a lesser extent Advenella kashmirensis displayed chitinase activity (Table 3), which can protect plant hosts against insect herbivores (Thamthiankul et al., 2004) and fungal pathogens (Liu et al., 2002). None of the strains displayed acid production in a methyl red assay (Glick, 1995).

\section{DISCUSSION}

Plant-microbe interactions of hyperaccumulator plant species is still a relatively unexplored area (Alford et al., 2010). The objectives of this study were to determine how endophytic microbial composition compares between Se hyperaccumulator (HA) species and non-hyperaccumulator species, and to characterize endophytic bacteria from Se hyperaccumulators. The main findings from T-RFLP analysis were that bacterial endophyte diversity represented by T-RFs pattern was comparable between Se HA and related non-HA growing on the same seleniferous site. TRFs composition appeared most similar between individuals of the same species. Beyond the species level, there was no apparent correlation of T-RFs composition with taxonomy, nor with plant Se concentration or spatial proximity in the field. The main findings from the HA endophyte characterization were that both species harbored a variety of culturable endophytes, comprising
66 morphotypes belonging to eight genera. The two plant species yielded similar numbers of endophytes, and these showed similar overall patterns. More endophytes could be cultivated from roots than shoots. The endophytes were highly Se resistant (up to $200 \mathrm{mM}$ generally), especially the root endophytes. All could reduce selenite to elemental Se. Selected endophytes showed evidence of plant growth promoting properties, both in in vitro assays as well as in vivo in plant growth studies.

The finding that there was no apparent relation between endophyte colonization and plant Se status (judged from T-RFLP analysis) suggests there is no cost of Se hyperaccumulation in terms of reduced endophyte colonization: Hyperaccumulators can enjoy the same benefits from bacterial endosymbionts as other plants. The finding that the T-RF pattern was most similar in individuals of the same species, even when located at a distance over $50 \mathrm{~m}$ indicates that each plant species hosts its specific consortium of endosymbionts that is transferred at least in part vertically, via the seed. Enclosed in seeds, endophytes may be dispersed in the field by animals or wind. In cases where endophytes reinoculate emerging seedlings from the rhizosphere, selective bacterial recruitment may be determined by root-released compounds, which may include selenocompounds (El-Mehdawi et al., 2012).

It is worth noting that T-RF pattern evaluation has several limitations in comparison to more informative next generation sequencing. Individual T-RF peaks may contain fragments with the same length but originating from different bacteria (in silico distinction is possible, e.g., by MICA3 software, Shyu et al., 2007). Also, since amplicons of plant plastid or mitochondrial DNA may be present after PCR, these may affect the efficiency of bacterial DNA amplification. In our study, the RFUs of mitochondrial T-RFs were at maximum $4.9 \times$ higher than other T-RFs 

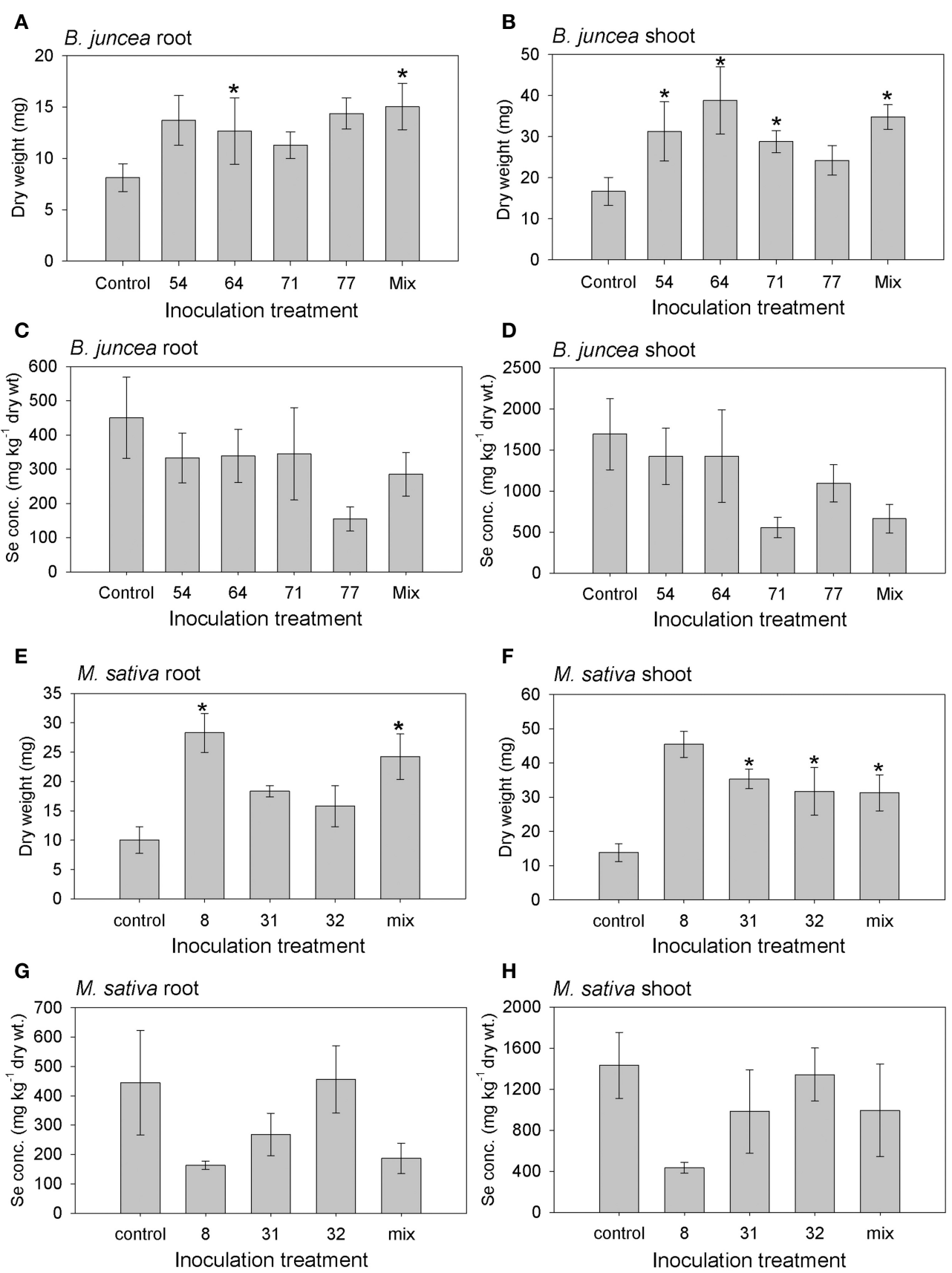

FIGURE 6 | Results from inoculation of $M$. sativa and $B$. juncea with endophytic bacteria isolated from Se hyperaccumulators

A. bisulcatus (\#8, 31, 32) and $S$. pinnata (\#54, 64, 71, 77), respectively. Additional treatments consisted of a mix of all 3 or 4 isolates, and an uninoculated control. (A) B. juncea root dry weight; (B) B. juncea shoot dry weight; (C) B. juncea root Se concentration; (D)

B. juncea shoot Se concentration; (E) M. sativa root dry weight; (F) $M$. sativa shoot dry weight; (G) $M$. sativa root Se concentration; (H) $M$. sativa shoot Se concentration. Shown values represent mean and standard error of the mean $(n=6)$. Asterisks denote significant differences as compared to the control treatment $(p<0.05$, Dunnett's multiple comparison test).

in the samples. It cannot be excluded that the least abundant bacterial species were not amplified due to template competition in the PCR reaction. Despite these limitations, comparison of T-RF patterns can give a valuable indication of endophytic diversity and composition.

Among the genera found in the HA plants in this study (Bacillus, Pantoea, Pseudomonas, Paenibacillus, Variovorax, Advenella, Arthrobacter, and Staphylococcus) some have also been reported as endophytic genera by other authors. Durán et al. (2014) found Bacillus, Paenibacillus, Klebsiella, and 
Table 3 | Plant growth promoting properties of the selected endophytes used for plant inoculation studies.

\begin{tabular}{|c|c|c|c|c|c|c|c|}
\hline $\mathbf{v v}$ & $\begin{array}{l}\text { Plant } \\
\text { source }\end{array}$ & ID & $\begin{array}{l}\text { Chitinase } \\
\text { activity }\end{array}$ & $\begin{array}{l}\text { Phosphate } \\
\text { solubilization }\end{array}$ & Protease activity & Acetoin & $\begin{array}{l}\text { Indole } \\
\text { acetic acid }\end{array}$ \\
\hline \#8 & $A B / L$ & Bacillus sp. & +++ & +- & +++ & +++ & - \\
\hline \#31 & $A B / R$ & Advenella kashmirensis & - & +++ & +++ & +++ & - \\
\hline \#32 & $A B / R$ & Pantoea agglomerans & - & +++ & - & +++ & +++ \\
\hline \#54 & $\mathrm{SP} / \mathrm{L}$ & Bacillus atrophaeus & +++ & +- & ++ & +++ & - \\
\hline \#64 & $\mathrm{SP} / \mathrm{R}$ & Arthrobacter sp. & - & - & - & - & - \\
\hline \#71 & $\mathrm{SP} / \mathrm{R}$ & Pseudomonas moraviensis & - & +++ & - & - & +++ \\
\hline \#77 & $\mathrm{SP} / \mathrm{R}$ & Pseudomonas sp. & - & +++ & +++ & +++ & +++ \\
\hline
\end{tabular}

For other properties of these accession numbers see Table 2. AB, isolated from Astragalus bisulcatus; SP, isolated from Stanleya pinnata; $L$, leaf; $R$, root.

Acinetobacter in Se-supplemented wheat plants. Weyens et al. (2009), Brader et al. (2014) and other authors Jackson et al. (2013), Pereira and Castro (2014), Truyens et al. (2014), Visioli et al. (2014) and Wang et al. (2014) have also identified several genera we isolated here as endophytic bacteria (Bacillus, Pseudomonas, Arthrobacter, Variovorax, Rhizobium, Rhodococcus, Burkholderia, Sphingomonas, Enterobacter, Microbacterium, Agreia, Sthenotrophomonas, Kocuria, Agrobacterium, Pantoea). The finding that Se HA plants growing in their natural seleniferous habitat harbor a variety of bacterial endophytes agrees with and extends the earlier reports that Se HA Astragalus bisulcatus contains Rhizobiaceae endophytes in root nodules as well as an endophytic fungus in seeds (Valdez Barillas et al., 2012). In the earlier studies these endophytes were hypothesized to be responsible for the high fraction (up to 30\%) of elemental Se found in these plants in the field (Lindblom et al., 2013). Indeed, all endophytes isolated in the current study were able to produce elemental Se, at least from selenite. In the plant, endophytic microbes may encounter selenate (the main form present in soil), selenite (metabolic intermediate) as well as various forms of organic selenocompounds accumulated in Se HA species (methyl-selenocysteine, selenocystathionine, as reported by Freeman et al., 2006). Thus, it is possible that these bacterial endophytes contribute to the observed elemental Se within HA plants in the field. Incidentally, it is relevant to note that all the experiments conducted in this study were performed under aerobic conditions; oxygen levels in some plant tissues may be lower.

Most endophytes isolated from HA plants were resistant to at least $10 \mathrm{mM}$ selenate and selenite and most could resist up to $200 \mathrm{mM}$ selenate (Figure 5). It is difficult to estimate what concentration of Se they may encounter in the HA plants. These plants tend to accumulate Se in all plant parts including roots, stems, leaves and seeds, up to $\sim 1.5 \%$ of DW $(0.15 \%$ of FW, or $1500 \mathrm{mg}$ Se per $\mathrm{kg} \mathrm{FW).} \mathrm{As} \mathrm{a} \mathrm{reference,} \mathrm{this} \mathrm{corresponds} \mathrm{to}$ $20 \mathrm{mM}$ selenite or selenate. The concentration in certain tissue types such as the epidermis may be higher (Freeman et al., 2006). Most Se in the plants is likely stored within the cells, while the endophytes may be present in between cells where Se levels are likely to be lower. It is also possible that some of these endophytes occur in the rhizosphere at times, e.g., if they are transferred horizontally. In the soil around these HA plants, the total Se concentration was measured in several earlier studies to be on average $15 \mathrm{mg} \mathrm{kg}^{-1}$, with a maximum of $100 \mathrm{mg} \mathrm{kg}^{-1}$ or ppm (Galeas et al., 2007; El-Mehdawi et al., 2011). Overall, the Se resistance displayed by the majority of these HA endophytes appears to be high enough to withstand the Se levels they are likely to encounter inside and around HA plants, with the possible exception of shoot Bacillus strains (Table 2, Figure 5). It is not clear why Se resistance was generally lower for shoot isolates than root isolates, considering that the Se levels are higher in the shoots than the roots of HA. Perhaps the root endophytes occur in locations where they encounter more plant Se (e.g., in the xylem, a transport route for Se from root to shoot) while in leaves the Se is sequestered in more discrete, symplastic locations (vacuoles, trichomes) away from endophytes. More studies are needed to assess whether the high degree of Se resistance observed for these $\mathrm{HA}$ endophytes is uncommon. For comparison, in a study by Di Gregorio et al. (2006) where rhizosphere bacteria were subjected to a period of selection for resistance to selenate and selenite, the reported resistance achieved was similar to that found for the Se HA endophytes here, and was also higher for selenate than selenite. Selenate/selenite resistance abilities of endophytic bacteria have also been described by Durán et al. (2014), who showed that strains isolated from Se-supplemented wheat were tolerant to Se levels ranging from 60 to $180 \mathrm{mM}$. Thus, the level of Se resistance observed in our current study, while high, may not be extraordinary. Nevertheless, based on our preliminary (unpublished) data, endophytes from non-HA plants on seleniferous soil and from non-HA from non-seleniferous soil appear less Se resistant than the endophytes reported here from HA plants. A more thorough comparison is in progress, which should offer some interesting insight into whether HA plants may select for endophyte Se resistance.

The Se resistance of the isolates was higher for selenate than for selenite, which may be due to different levels of bacterial uptake or extrusion rates, or different detoxification mechanisms. It is interesting to note that strains that were more selenite-resistant were generally also more selenate-resistant, which may indicate that some of the bacterial resistance mechanisms are shared for both Se oxyanions. Our finding that these HA endophytes can all convert selenite into elemental Se, while none can do the same for selenate is not unexpected. Many bacteria can reduce selenite, while selenate reduction is rare (Vallini et al., 2005; Hunter and Manter, 2009; Mishra et al., 2011; Staicu et al., under revision). The conversion of selenite to elemental Se may serve as a bacterial 
detoxification mechanism (Kessi et al., 1999), since endophyte growth was never stimulated by selenite in our studies. The mechanism of selenite reduction to elemental Se in these endophytes remains to be determined. Bacteria are known to be able to use different selenite reduction mechanisms, which may involve hydrogenase (Yanke et al., 1995), arsenate reductase (Afkar et al., 2003), nitrate reductase (Avazeri et al., 1997), nitrite reductase (Bledsoe et al., 1999), glutathione reductase or thioredoxin reductase (Hunter, 2014). In addition, Zawadzka et al. (2006) showed that siderophores of Pseudomonas stutzeri KC were able to detoxify Se and tellurium oxyanions in bacterial cultures. All cultivable isolates in our study produced siderophores, which in some cases may have contributed to their Se resistance. All our endophyte isolates were also able to reduce nitrite, so nitrite reductase may also be a mechanism some of them employ for selenite reduction. Nitrate inhibited selenite reduction and, hence, growth for some of our isolates but not others (Table 2), which may indicate the selenite reduction mechanisms are not the same for all isolates. The capacity of bacteria to reduce selenite may be applicable for treatment of wastewater as well as for the production of Se nanoparticles for industrial purposes (Staicu et al., under revision). Polluted water from oil refineries can contain $20-30 \mathrm{mg}$ Se $\mathrm{L}^{-1}$ in the form of selenite (Hansen et al., 1998), and bacteria such as those described in this study may be applicable for the treatment of such wastewaters.

Besides potentially being useful by themselves, endophytic bacteria may also be useful via their positive effects on plant growth, nutritional quality and elemental accumulation. Plantassociated bacteria can affect the efficiency and rate of phytoextraction of trace elements in contaminated soils (Sessitsch et al., 2013). In the case of Se this is relevant for phytoremediation and biofortification, since Se can both be toxic and serve as a nutrient. The seven isolates that were tested in this study showed a general tendency to enhance the growth of M. sativa and B. juncea, while not significantly affecting Se accumulation (Figure 6). The possible mechanisms by which these endophytes caused the observed positive effect on plant growth may lie in the observed chitinase activity, phosphate solubilization activity, protease activity, acetoin production and/or IAA plant growth hormone production (Table 3). The different isolates differed with respect to these activities. Another potential plant growth promoting property that all isolates displayed was the production of siderophores, possibly aiding plants in acquiring nutritional iron from soil. This may explain why one isolate (\#64, Table 3) did not display any of the other plant growth promoting properties, yet still had a positive effect on the plant growth. It remains to be determined whether this plant growth stimulation by these endophytes is Sedependent or not, but based on preliminary (unpublished) results from plants grown on gravel and supplied with or without selenate, the positive effect on growth occurs both with and without selenate.

While the shoot and root Se levels of $M$. sativa and B. juncea were not significantly different between inoculated and control plants, it is worth noting that on average the inoculated plants contained lower tissue Se levels in this experiment (Figure 6). More experiments are needed to determine whether this trend may be significant with more replication. It is feasible that bacterial endophytes volatilize Se from the plant tissues, thus causing lower Se levels in inoculated plants. It is also possible that the inoculated bacteria were also present in the rhizosphere, and there reduced plant Se bioavailability by, e.g., elemental Se production, or competed with the plant for Se uptake. Some of the Se in this seleniferous soil, which was collected from around Se hyperaccumulators in the field, may have been in organic forms (El Mehdawi et al., 2015). This organic Se may constitute an attractive carbon source for rhizosphere bacteria. If indeed a substantial fraction of the Se in this soil was organic, this may also explain the high plant tissue Se levels observed (Figure 6). Brassica juncea has been shown in earlier studies to reach much higher bioaccumulation levels from organic forms of Se than from selenate or selenite (Zayed et al., 1998; de Souza et al., 2001). Preliminary results from plants grown on gravel and supplied with selenate indicate that inoculation with these same endophyte strains can cause plant Se levels to be enhanced. More extensive studies are needed to confirm this, but it is feasible that endophyte inoculation affects plant Se accumulation differently, depending on the form of Se supplied. In an earlier study by de Souza et al. (1999) rhizosphere bacteria from a seleniferous area were shown to enhance Indian mustard growth as well as selenate uptake and volatilization. The mechanism likely involved stimulated root hair production, perhaps via bacterial IAA production. Furthermore, Di Gregorio et al. (2006) showed that certain bacteria from the plant rhizosphere or endosphere can have positive effects on plant Se decontamination through either phytoextraction or putative volatilization on Se-rich soil. More recently, several soil bacteria isolated from a polluted area were shown to enhance wheat growth and Se accumulation (Yasin et al., 2015). More studies are needed to determine the long-term effects of these endophyte strains on growth and Se accumulation of different plant species, growth substrates and forms of Se supplied. Such studies will be useful to determine the potential of these strains to enhance the efficiency of Se biofortification and phytoremediation practices. If indeed these strains can enhance plant growth and/or affect Se accumulation, this will be particularly useful for phytoextraction, since this type of phytoremediation usually requires several years to clean up the contaminated site (Macek et al., 2000; Pilon-Smits, 2005; Mackova et al., 2009; Vangronsveld et al., 2009). Future studies with different plant-microbe combinations may also help shed more light on the individual interactions between plants and individual or combinations of microbes. This may allow us to optimally employ the symbiotic synergisms between plants and their microbiomes for phytoremediation.

\section{ACKNOWLEDGMENTS}

We thank the Czech Ministry of Education, Youth and Sports for financial support through the project KONTAKT LH12087. Our special thanks belong to Bram Beckers from Hasselt University, Belgium, who consulted with us regarding the analysis of the total bacterial DNA of endophytes and to Ronald de Jong from Altenburg \& Wymenga, Netherlands, who helped us create the map for Figure 1.

\section{SUPPLEMENTARY MATERIAL}

The Supplementary Material for this article can be found online at: http://www.frontiersin.org/journal/10.3389/fpls.2015.00113/ abstract 
Supplemental Table 1 | Matrix scoring the presence or absence of each T-RF in each individual plant. The presence of T-RF is represented by " 1 ," the absence of the T-RF is represented by " 0 ." Column A represents the size of T-RFs. Ab4, Ab5, Ab10-samples of hyperaccumulators Astragalus bisulcatus; Sp5, Sp14, and Sp30-samples of hyperaccumulators Stanleya pinnata; Ms25, Ms26-samples of non-hyperaccumalating plants of Medicago sativa $\mathrm{L}$.; Pb22, Pb23, Pb24-samples of non-hyperaccumalating plants of Physaria bellii G. Mulligan.

\section{Supplemental Table 2 | Macroscopic and microscopic characterization of individual endophytic isolates used for detrended canonical \\ correspondence analysis (CANOCO). The presence of studied}

characteristic is represented by " 1, " the absence is represented by " 0. " Row 1 describes characteristic, row 2 represent the abbreviation used in the analysis.

\section{REFERENCES}

Afkar, E., Lisak, J., Saltikov, C., Basu, P., Oremland, R. S., and Stolz, J. F. (2003). The respiratory arsenate reductase from Bacillus selenitireducens strain MLS10. FEMS Microbiol. Lett. 226, 107-112. doi: 10.1016/S0378-1097(03) 00609-8

Alford, E. A., Pilon-Smits, E. A. H., Paschke, M. (2010). Metallophytes-a view from the rhizosphere. Plant Soil 337, 33-50. doi: 10.1007/s11104-010-0482-3

Amann, R. I., Ludwig, W., and Schleifer, K. H. (1995). Phylogenetic identification and in situ detection of individual microbial cells without cultivation. Microbiol. Rev. 59, 143-169.

Avazeri, C., Turner, R. J., Pommier, J., Weiner, J. H., Giordano, G., and Vermeglio, A. (1997). Tellurite reductase activity of nitrate reductase is responsible for the basal resistance of Escherichia coli to tellurite. Microbiology 143, 1181-1189. doi: 10.1099/00221287-143-4-1181

Bãnuelos, G. S., Walse, S. S., Pickering, I. J., Fakra, S. C., Marcus, M. A., PilonSmits, E. A. H., et al. (2011). Localization, chemical speciation, and semiquantification of selenium in cactus pear, Opuntia ficus-indica, grown in saline drainage sediment. Plant Physiol. 155, 315-327.

Barac, T., Taghavi, S., Borremans, B., Provoost, A., Oeyen, L., Colpaert, J. V., et al. (2004). Engineered endophytic bacteria improve phytoremediation of water-soluble, volatile, organic pollutants. Nat. Biotechnol. 22, 583-588. doi: $10.1038 / \mathrm{nbt} 960$

Bledsoe, T. L., Cantafio, A. W., and Macy, J. M. (1999). Fermented whey-an inexpensive feed source for a laboratory-scale selenium-bioremediation reactor system inoculated with Thauera selenatis. Appl. Microbiol. Biotechnol. 51, 682-685. doi: 10.1007/s002530051452

Bonner, J., and Bandurski, R. S. (1952). Studies of the physiology, pharmacology, and biochemistry of the auxins. Annu. Rev. Plant Physiol. 3, 59-86. doi: 10.1146/annurev.pp.03.060152.000423

Brader, G., Compant, S., Mitter, B., Trognitz, F., and Sessitsch, A. (2014). Metabolic potential of endophytic bacteria. Curr. Opin. Biotechnol. 27, 30-37. doi: 10.1016/j.copbio.2013.09.012

Cappa, J. J., and Pilon-Smits, E. A. H. (2014). Evolutionary aspects of hyperaccumulation. Planta 239, 267-275. doi: 10.1007/s00425-013-1983-0

Chen, B., Shen, J., Zhang, X., Pan, F., Yang, X., and Feng, Y. (2014). The endophytic bacterium, Sphingomonas SaMR12, improves the potential for zinc phytoremediation by its host, Sedum alfredii. PLoS ONE 9:e106826. doi: 10.1371/journal.pone.0106826

Cho, K. M., Hong, S. Y., Lee, S. M., Kim, Y. H., Kahng, G. G., Lim, Y. P., et al. (2007). Endophytic bacterial communities in ginseng and their antifungal activity against pathogens. Microb. Ecol. 54, 341-351. doi: 10.1007/s00248-0079208-3

Compant, S., Reiter, B., Sessitsch, A., Nowak, J., and Clement, C. (2005). Endophytic colonization of Vitis vinifera L. by plant growth-promoting bacterium Burkholderia sp. strain PsJN. Appl. Environ. Microbiol. 71, 1685-1693. doi: 10.1128/AEM.71.4.1685-1693.2005

Croes, S., Weyens, N., Colpaert, J., and Vangronsveld, J. (2014). Characterization of the cultivable bacterial populations associated with field grown Brassica napus L.: an evaluation of sampling and isolation protocols. Environ. Microbiol. doi: $10.1111 / 1462-2920.12701$ de Souza, M. P., Amini, A., Dojka, M. A., Pickering, I. J., Dawson, S. C., Pace, N. R., et al. (2001). Identification and characterization of bacteria in a seleniumcontaminated hypersaline evaporation pond. Appl. Environ. Microbiol. 67, 3785-3794. doi: 10.1128/AEM.67.9.3785-3794.2001

de Souza, M. P., Chu, D., Zhao, M., Zayed, A. M., Ruzin, S. E., Schichnes, D., et al. (1999). Rhizosphere bacteria enhance selenium accumulation and volatilization by Indian mustard. Plant Physiol. 119, 565-574. doi: 10.1104/pp.119.2.565

Di Gregorio, S., Lampis, S., Malorgio, F., Petruzzelli, G., Pezzarossa, B., and Vallini, G. (2006). Brassica juncea can improve selenite and selenate abatement in selenium contaminated soils through the aid of its rhizospheric bacterial population. Plant Soil 285, 233-244. doi: 10.1007/s11104-006-9010-x

Doty, S. L., Oakley, B., Xin, G., Kang, J. W., Singleton, G., Khan, Z., et al. (2009). Diazotrophic endophytes of native black cottonwood and willow. Curr. Microbiol. 47, 23-33. doi: 10.1007/BF03179967

Dowling, D. N., Germaine, K., Franks, A., Ryan, R. P., and Ryan, D. J. (2008). Bacterial endophytes: recent developments and applications. FEMS Microbiol. Lett. 278, 1-9. doi: 10.1111/j.1574-6968.2007.00918.x

Durán, P., Acuña, J., Jorquera, M., Azcón, R., Paredes, C., Rengel, Z., et al. (2014). Endophytic bacteria from selenium-supplemented wheat plants could be useful for plant-growth promotion, biofortification and Gaeumannomyces graminis biocontrol in wheat production. Biol. Fertil. Soils 50, 983-990. doi: 10.1007/s00374-014-0920-0

El-Mehdawi, A. F., Cappa, J. J., Fakra, S. C., Self, J., and Pilon-Smits, E. A. H. (2012). Interactions of selenium and non-accumulators during co-cultivation on seleniferous or non-seleniferous soil-the importance of having good neighbors. New Phytol. 194, 264-277. doi: 10.1111/j.1469-8137.2011.04043.x

El-Mehdawi, A. F., and Pilon-Smits, E. A. H. (2012). Ecological aspects of plant selenium hyperaccumulation. Plant Biol. 14, 1-10. doi: 10.1111/j.14388677.2011.00535.x

El Mehdawi, A. F., Lindblom, S. D., Cappa, J. J., Fakra, S. C., and Pilon-Smits, E. A. H. (2015). Do selenium hyperaccumulators affect selenium speciation in neighboring plants and soil? An X-ray microprobe analysis. Int. J. Phytoremediation 17.

El-Mehdawi, A. F., Quinn, C. F., and Pilon-Smits, E. A. H. (2011). Effects of selenium hyperaccumulation on plant-plant interactions: evidence for elemental allelopathy? New Phytol. 191, 120-131. doi: 10.1111/j.1469-8137.2011.03670.x

Farinati, S., DalCorso, G., Bona, E., Corbella, M., Lampis, S., Cecconi, D., et al. (2009). Proteomic analysis of Arabidopsis halleri shoots in response to the heavy metals cadmium and zinc and rhizosphere microorganisms. Proteomics 9, 4837-4850. doi: 10.1002/pmic.200900036

Farinati, S., DalCorso, G., Panigati, M., and Furini, A. (2011). Interaction between selected bacterial strains and Arabidopsis halleri modulates shoot proteome and cadmium and zinc accumulation. J. Exp. Bot. 62, 3433-3447. doi: $10.1093 /$ jxb/err015

Farris, J. S., Albert, V. A., Källersjö, M., Lipscomb, D., and Kluge, A. G. (1996). Parsimony jackknifing outperforms neighbor-joining. Cladistics 12, 99-124. doi: 10.1111/j.1096-0031.1996.tb00196.x

Fassel, V. A. (1978). Quantitative elemental analyses by plasma emission spectroscopy. Science 202, 183-191. doi: 10.1126/science.202.4364.183

Freeman, J. L., Zhang, L. H., Marcus, M. A., Fakra, S., McGrath, S. P., and Pilon-Smits, E. A. H. (2006). Spatial imaging, speciation and quantification of selenium in the hyperaccumulator plants Astragalus bisulcatus and Stanleya pinnata. Plant Physiol. 142, 124-134. doi: 10.1104/pp.106.081158

Galeas, M. L., Klamper, E. M., Bennett, L. E., Freeman, J. L., Kondratieff, B. C., Quinn, C. F., et al. (2008). Selenium hyperaccumulation reduced plant arthropod loads in the field. New Phytol. 177, 715-724. doi: 10.1111/j.14698137.2007.02285.x

Galeas, M. L., Zhang, L. H., Freeman, J. L., Wegner, M., and Pilon-Smits, E. A. H. (2007). Seasonal fluctuations of selenium and sulfur accumulation in selenium hyperaccumulators and related non-accumulators. New Phytol. 173, 517-525. doi: 10.1111/j.1469-8137.2006.01943.x

Germaine, K. J., Liu, X., Cabellos, G. G., Hogan, J. P., Ryan, D., and Dowling, D. N. (2003). Bacterial endophyte-enhanced phytoremediation of the organochlorine herbicide 2, 4- dichlorophenoxyacetic acid. FEMS Microbiol. Ecol. 57, 302-310. doi: 10.1111/j.1574-6941.2006.00121.x

Glick, B. R. (1995). The enhancement of plant growth by free-living bacteria. Can. J. Microbiol. 41, 109-117. doi: 10.1139/m95-015

Glick, B. R. (2012). Plant growth-promoting bacteria: mechanisms and applications. Scientifica (Cairo). 2012:963401. doi: 10.6064/2012/963401 
Green, L. C., Wagner, D. A., Glogowski, J., Skipper, P. L., Wishnok, J. S., and Tannenbaum, S. R. (1982). Analysis of nitrate, nitrite and $\left[{ }^{15} \mathrm{~N}\right]$ nitrate in biological fluids. Anal. Biochem.126, 131-138. doi: 10.1016/0003-2697(82)90118-X

Guan, S. H., Sattler, I., Lin, W. H., Guo, D. A., and Grabley, S. (2005). pAminoacetophenonic acids produced by a mangrove endophyte: Streptomyces griseus subspecies. J. Nat. Prod. 68, 1198-1200. doi: 10.1021/np0500777

Gupta, A., Gopal, M., and Tilak, K. V. (2000). Mechanism of plant growth promotion by rhizobacteria. Indian J. Exp. Biol. 38, 856-862.

Hansen, D., Duda, P., Zayed, A. M., and Terry, N. (1998). Selenium removal by constructed wetlands: role of biological volatiliza tion. Environ. Sci. Technol. 32, 591-597. doi: 10.1021/es9705021

Hanson, B., Garifullina, G. F., Lindblom, S. D., Wangeline, A., Ackley, A., Kramer, K., et al. (2003). Selenium accumulation protects Brassica juncea from invertebrate herbivory and fungal infection. New Phytol. 159, 461-469. doi: 10.1046/j.1469-8137.2003.00786.x

Harris, J., Schneberg, K. A., and Pilon-Smits, E. A. H. (2014). Sulfur-seleniummolybdenum interactions distinguish selenium hyperaccumulator Stanleya pinnata from non-hyperaccumulator Brassica juncea (Brassicaceae). Planta 239, 479-491. doi: 10.1007/s00425-013-1996-8

Hunter, W. J. (2014). Pseudomonas seleniipraecipitans proteins potentially involved in selenite reduction. Curr. Microbiol. 69, 69-74. doi: 10.1007/s00284-0140555-2

Hunter, W. J., and Manter, D. K. (2009). Reduction of selenite to elemental red selenium by Pseudomonas sp. strain CA5. Curr. Microbiol. 58, 493-498. doi: 10.1007/s00284-009-9358-2

Jackson, C. R., Randolph, K. C., Osborn, S. L., and Tyler, H. L. (2013). Culture dependent and independent analysis of bacterial communities associated with commercial salad leaf vegetables. BMC Microbiol. 13:274. doi: 10.1186/14712180-13-274

Jha, N. P., Gupta, G., Jha, P., and Mehrotra, R. (2013). Association of rhizospheric/endophytic bacteria with plants: a potential gateway to sustainable agriculture. Greener J. Agri. Sci. 3, 73-84.

Kessi, J., Ramuz, M., Wehrli, E., Spycher, M., and Bachoefen, R. (1999). Reduction of selenite and detoxification of elemental selenium by the phototrophic bacterium Rhodospirillum rubrum. Appl. Environ. Microbiol. 65, 4734-4740.

Lane, D. J. (1991). “16S/23S rRNA sequencing," in Nucleic Acid Techniques in Bacterial Systematics, eds E. Stackebrandt and M. Goodfellow (New York, NY: John Wiley and Sons), 115-176.

Li, W. C., and Wong, M. H. (2012). Interaction of Cd/Zn hyperaccumulating plant (Sedum alfredii) and rhizosphere bacteria on metal uptake and removal of phenanthrene. J. Hazard. Mater. 209-210, 421-433. doi: 10.1016/j.jhazmat.2012.01.055

Lindblom, S. D., Valdez-Barillas, J. R., Fakra, S. C., Marcus, M. A., Wangeline, A. L., and Pilon-Smits, E. A. H. (2013). Influence of microbial associations on selenium localization and speciation in roots of Astragalus and Stanleya hyperaccumulators. Environ. Exp. Bot. 88, 33-42. doi: 10.1016/j.envexpbot.2011. 12.011

Liu, M., Cai, Q. X., Liu, H. Z., Zhang, B. H., Yan, J. P., and Yuan, Z. M. (2002). Chitinolytic activities in Bacillus thuringiensis and their synergistic effects on larvicidal activity. J. Appl. Microbiol. 93, 374-379. doi: 10.1046/j.13652672.2002.01693.x

Lodewyckx, C., Vangronsveld, J., Porteous, F., Moore, E. R. B., Taghavi, S., Mezgeay, M., et al. (2002). Endophytic bacteria and their potential applications. Crit. Rev. Plant Sci. 21, 583-606. doi: 10.1080/0735-260291044377

Macek, T., Macková, M., and Kás, J. (2000). Exploitation of plants for the removal of organics in environmental remediation. Biotechnol. Adv. 18, 23-34. doi: 10.1016/S0734-9750(99)00034-8

Mackova, M., Prouzova, P., Stursa, P., Ryslava, E., Uhlik, O., Beranova,. K., et al. (2009). Phyto/rhizoremediation studies using long-term PCB-contaminated soil. Environ. Sci. Pollut. Res. Int. 16, 817-829. doi: 10.1007/s11356-009-0240-3

Miller, C. M., Miller, R. V., Garton-Kenny, D., Redgrave, B., Sears, J., Condron, M. M., et al. (1998). Ecomycins, unique antimycotics from Pseudomonas viridiflava. J. Appl. Microbiol. 84, 937-944. doi: 10.1046/j.1365-2672.1998.00415.x

Mishra, R. R., Parajapati, S., Das, J., Dangar, T. K., Das, N., and Thatoi, H. (2011). Reduction of selenite to red elemental selenium by moderately halotolerant Bacillus megaterium strains isolated from Bhitarkanika mangrove soil and characterization of reduced product. Chemosphere 84, 1231-1237. doi: 10.1016/j.chemosphere.2011.05.025
Moore, F. P., Barac, T., Borremans, B., Oeyen, L., Vangronsveld, J., van der Lelie, D., et al. (2006). Endophytic bacterial diversity in poplar trees growing on a BTEX-contaminated site: the characterization of isolates with potential to enhance phytoremediation. Syst. Appl. Microbiol. 29, 539-556. doi: 10.1016/j.syapm.2005.11.012

Murashige, T., and Skoog, F. (1962). A revised medium for rapid growth and bioassays with tobacco tissue culture. Physiol. Plant. 15, 437-497. doi: 10.1111/j.13993054.1962.tb08052.x

Pereira, S. I., and Castro, P. M. (2014). Diversity and characterization of culturable bacterial endophytes from Zea mays and their potential as plant growthpromoting agents in metal-degraded soils. Environ. Sci. Pollut. Res. Int. 21, 14110-14123. doi: 10.1007/s11356-014-3309-6

Pilon-Smits, E. A. H. (2005). Phytoremediation. Annu. Rev. Plant Biol. 56, 15-39. doi: 10.1146/annurev.arplant.56.032604.144214

Quinn, C. F., Freeman, J. L., Reynolds, R. J., Cappa, J. J., Fakra, S. C., Marcus, M. A., et al. (2010). Selenium hyperaccumulation offers protection from cell disruptor herbivores. BMC Ecol. 10:19. doi: 10.1186/1472-6785-10-19

Quinn, C. F., Wyant, K., Wangeline, A. L., Shulman, J., Galeas, M. L., Valdez, J. R., et al. (2011). Selenium hyperaccumulation increases leaf decomposition rate in a seleniferous habitat. Plant Soil 341, 51-61. doi: 10.1007/s11104-0100446-7

Qureshi, M. A., Ahmad, Z. A., Akhtar, N., Iqbal, A., Mujeeb, F., and Shakir, M. A. (2012). Role of phosphate solubilizing bacteria (psb) in enhancing P availability and promoting cotton growth. J. Anim. Plant Sci. 22, 204-210.

Ryan, R. P., Germaine, K., Franks, A., Ryan, D. J., and Dowling, D. N. (2008). Bacterial endophytes: recent developments and applications. FEMS Microbiol. Lett. 278, 1-9. doi: 10.1111/j.1574-6968.2007.00918.x

Ryu, C., Farag, M. A., Hu, C., Reddy, M. S., Wei, H., Paré, P. W., et al. (2003). Bacterial volatiles promote growth in Arabidopsis. Proc. Natl. Acad. Sci. U.S.A. 100, 4927-4932. doi: 10.1073/pnas.0730845100

Sessitsch, A., Kuffner, M., Kidd, P., Vangronsveld, J., Wenzel, W. W., Fallmann, K., et al. (2013). The role of plant-associated bacteria in the mobilization and phytoextraction of trace elements in contaminated soils. Soil Biol. Biochem. 60, 182-194. doi: 10.1016/j.soilbio.2013.01.012

Shin, S. H., Lim, Y., Lee, S. E., Yang, N. W., and Rhee, J. H. (2001). CAS agar diffusion assay for the measurement of siderophores in biological fluids. J. Microbiol. Methods 44, 89-95. doi: 10.1016/S0167-7012(00)00229-3

Shyu, C., Soule, T., Bent, S. J., Foster, J. A., and Forney, L. J. (2007). MiCA: a web-based tool for the analysis of microbial communities based on terminalrestriction fragment length polymorphisms of $16 \mathrm{~S}$ and 18S rRNA genes. J. Microb. Ecol. 53, 562-570. doi: 10.1007/s00248-006-9106-0

Staicu, L. C., van Hullebusch, E. D., Lens, P. N. L., Pilon-Smits, E. A. H., and Oturan, M. A. (2015). Electrocoagulation of colloidal biogenic selenium. Environ. Sci. Pollut. Res. Int. 22, 3127-3137. doi: 10.1007/s11356-014-3592-2

Strobel, G., Daisy, B., Castillo, U., and Harper, J. (2004). Natural products from endophytic microorganisms. J. Nat. Prod. 67, 257-268. doi: 10.1021/np030397v

Swofford, D. L. (2001). PAUP*: Phylogenetic Analysis Using Parsimony ( ${ }^{*}$ and Other Methods). Sunderland, MA: Sinauer.

Taghavi, S., Barac, T., Greenberg, B., Vangronsveld, J., and van der Lelie, D. (2005). Horizontal gene transfer to endogenous endophytic bacteria from poplar improves phytoremediation of toluene. Appl. Environ. Microbiol. 71, 8500-8505. doi: 10.1128/AEM.71.12.8500-8505.2005

Taghavi, S., van der Lelie, D., Hoffman, A., Zhang, Y. B., and Walla, M. D. (2010). Genome sequence of the plant growth promoting endophytic bacterium Enterobacter sp. PLoS Genet. 28, 346-358. doi: 10.1371/journal.pgen.1000943

ter Braak, C. J. F., and Šmilauer, P. (1998). CANOCO Reference Manual and User's Guide to Canoco for Windows. Software for Canonical Community Ordination (Version 4). Wageningen: Centre of Biometry.

Thamthiankul, S., Moar, W. J., Miller, M. E., and Panbangred, W. (2004). Improving the insecticidal activity of Bacillus thuringiensis subsp. aizawai against Spodoptera exigua by chromosomal expression of a chitinase gene. Appl. Microbiol. Biotechnol. 65, 183-192. doi: 10.1007/s00253-004-1606-6

Truyens, S., Jambon, I., Croes, S., Janssen, J., Weyens, N., Mench, M., et al. (2014). The effect of long-term Cd and Ni exposure on seed endophytes of Agrostis capillaris and their potential application in phytoremediation of metal-contaminated soils. Int. J. Phytoremediation. 16, 643-659. doi: 10.1080/15226514.2013. 837027

Uhlik, O., Strejcek, M., Junkova, P., Sanda, M., Hroudova, M., Vlcek, C., et al. (2011). Matrix-assisted laser desorption ionization (MALDI)-time of 
flight mass spectrometry- and MALDI biotyper-based identification of cultured biphenyl-metabolizing bacteria from contaminated horseradish rhizosphere soil. Appl. Environ. Microbiol. 77, 6858-6866. doi: 10.1128/AEM. 05465-1

Ulrich, K., Ulrich, A., and Ewald, D. (2008). Diversity of endophytic bacterial communities in poplar grown under field conditions. FEMS Microbiol. Ecol. 63, 169-180. doi: 10.1111/j.1574-6941.2007.00419.x

Valdez Barillas, J. R., Quinn, C. F., Freeman, J. L., Lindblom, S. D., Marcus, M. S., Fakra, S. C., et al. (2012). Selenium distribution and speciation in hyperaccumulator Astragalus bisulcatus and associated ecological partners. Plant Physiol. 159, 1834-1844. doi: 10.1104/pp.112.199307

Vallini, G., Di Gregorio, S., and Lampis, S. (2005). Rhizosphere-induced selenium precipitation for possible applications in phytoremediation of Se polluted effluents. Z. Naturforsch. 60C, 349-356. doi: 10.1515/znc-2005-3-419

Vangronsveld, J., Herzig, R., Weyens, N., Boulet, J., Adriaensen, K., Ruttens, A., et al. (2009). Phytoremediation of contaminated soils and groundwater: lessons from the field. Environ. Sci. Pollut. Res. Int. 16, 765-794. doi: 10.1007/s11356009-0213-6

Visioli, G., D’Egidio, S., Vamerali, T., Mattarozzi, M., and Sanangelantoni, A. M. (2014). Culturable endophytic bacteria enhance Ni translocation in the hyperaccumulator Noccaea caerulescens. Chemosphere 117C, 538-544. doi: 10.1016/j.chemosphere.2014.09.014

Wang, Y., Yang, X., Zhang, X., Dong, L., Zhang, J., Wei, Y., et al. (2014). Improved plant growth and $\mathrm{Zn}$ accumulation in grains of rice (Oryza sativa L.) by inoculation of endophytic microbes isolated from a $\mathrm{Zn}$ Hyperaccumulator, Sedum alfredii H. J. Agric. Food Chem. 62, 1783-1791. doi: 10.1021/jf4 $04152 \mathrm{u}$

Weyens, N., Gielen, M., Beckers, B., Boulet, J., van der Lelie, D., Taghavi, S., et al. (2013). Bacteria associated with yellow lupine grown on a metalcontaminated soil: in vitro screening and in vivo evaluation for their potential to enhance Cd phytoextraction. Plant Biol. 16, 988-996. doi: 10.1111/ plb.12141

Weyens, N., van der Lelie, D., Taghavi, S., and Vangronsveld, J. (2009). Phytoremediation: plant-endophyte partnerships take the challenge. Curr. Opin. Biotechnol. 20, 248-254. doi: 10.1016/j.copbio.2009.02.012

Yanke, L. J., Bryant, R. D., and Laishley, E. J. (1995). Hydrogenase (I) of Clostridium pasteurianum functions a novel selenite reductase. Anaerobe 1, 61-67. doi: 10.1016/S1075-9964(95)80457-9

Yasin, M., El-Mehdawi, A. F., Anwar, A., Pilon-Smits, E. A. H., and Faisal, M. (2015). Microbial-enhanced selenium and iron biofortification of wheat
(Triticum aestivum L.) —Applications in phytoremediation and biofortification. Int. J. Phytorem. 17, 341-347. doi: 10.1080/15226514.2014.922920

Zarcinas, B. A., Cartwright, B., and Spouncer, L. R. (1987). Nitric acid digestion and multielement analysis of plant material by inductively coupled plasma spectrometry. Commun. Soil. Sci. Plant Anal. 18, 131-146. doi: $10.1080 / 00103628709367806$

Zawadzka, A. M., Crawford, R. L., and Paszczynski, A. J. (2006). Pyridine-2,6bis(thiocarboxylic acid) produced by Pseudomonas stutzeri $\mathrm{KC}$ reduces and precipitates selenium and tellurium oxyanions. Appl. Environ. Microbiol. 72, 3119-3129. doi: 10.1128/AEM.72.5.3119-3129.2006

Zayed, A., Gowthaman, S., and Terry, N. (1998). Phytoaccumulation of trace elements by wetland plants: I. Duckweed. J. Environ. Qual. 27, 715-721. doi: 10.2134/jeq1998.00472425002700030032x

Zhu, Y.-G., Pilon-Smits, E. A. H., Zhao, F.-J., Williams, P. N., and Meharg, A. A. (2009). Selenium in higher plants: understanding mechanisms for biofortification and phytoremediation. Trends Plant Sci. 19, 436-442. doi: 10.1016/j.tplants.2009.06.006

Conflict of Interest Statement: The authors declare that the research was conducted in the absence of any commercial or financial relationships that could be construed as a potential conflict of interest.

Received: 30 November 2014; accepted: 11 February 2015; published online: 02 March 2015.

Citation: Sura-de Jong M, Reynolds RJB, Richterova K, Musilova L, Staicu LC, Chocholata I, Cappa JJ, Taghavi S, van der Lelie D, Frantik T, Dolinova I, Strejcek $M$, Cochran AT, Lovecka P and Pilon-Smits EAH (2015) Selenium hyperaccumulators harbor a diverse endophytic bacterial community characterized by high selenium resistance and plant growth promoting properties. Front. Plant Sci. 6:113. doi: 10.3389/fpls. 2015.00113

This article was submitted to Plant Biotechnology, a section of the journal Frontiers in Plant Science.

Copyright (c) 2015 Sura-de Jong, Reynolds, Richterova, Musilova, Staicu, Chocholata, Cappa, Taghavi, van der Lelie, Frantik, Dolinova, Strejcek, Cochran, Lovecka and Pilon-Smits. This is an open-access article distributed under the terms of the Creative Commons Attribution License (CC BY). The use, distribution or reproduction in other forums is permitted, provided the original author(s) or licensor are credited and that the original publication in this journal is cited, in accordance with accepted academic practice. No use, distribution or reproduction is permitted which does not comply with these terms. 